\title{
In vitro biocompatibility and bioactivity of calcium silicate-based bioceramics in endodontics (Review)
}

\author{
WENCHENG SONG ${ }^{1-3^{*}}$, SHUE LI ${ }^{1-3 *}$, QINGMING TANG ${ }^{1-3}$, LILI CHEN $^{1-3}$ and ZHENGLIN YUAN ${ }^{1-3}$ \\ ${ }^{1}$ Department of Stomatology, Union Hospital, Tongji Medical College, Huazhong University of Science and Technology, \\ Wuhan, Hubei 430022; ${ }^{2}$ School of Stomatology, Tongji Medical College, Huazhong University of \\ Science and Technology, Wuhan, Hubei 430030; ${ }^{3}$ Hubei Province Key Laboratory of Oral and \\ Maxillofacial Development and Regeneration, Wuhan, Hubei 430022, P.R. China
}

Received November 3, 2020; Accepted March 19, 2021

DOI: $10.3892 / \mathrm{ijmm} .2021 .4961$

\begin{abstract}
Calcium silicate-based bioceramics have been applied in endodontics as advantageous materials for years. In addition to excellent physical and chemical properties, the biocompatibility and bioactivity of calcium silicate-based bioceramics also serve an important role in endodontics according to previous research reports. Firstly, bioceramics affect cellular behavior of cells such as stem cells, osteoblasts, osteoclasts, fibroblasts and immune cells. On the other hand, cell reaction to bioceramics determines the effect of wound healing and tissue repair following bioceramics implantation. The aim of the present review was to provide an overview of calcium silicate-based bioceramics currently applied in endodontics, including mineral trioxide aggregate, Bioaggregate, Biodentine and iRoot, focusing on their in vitro biocompatibility and bioactivity. Understanding their underlying mechanism may help to ensure these materials are applied appropriately in endodontics.
\end{abstract}

\section{Contents}

1. Introduction

2. Stem cells

3. Osteoblasts/osteoclasts

4. Dental pulp or periodontal ligament cells/fibroblasts (PDLC/Fs)

5. Immune cells

6. Conclusion

Correspondence to: Professor Lili Chen or Professor Zhenglin Yuan, Department of Stomatology, Union Hospital, Tongji Medical College, Huazhong University of Science and Technology, 1277 Jiefang Avenue, Wuhan, Hubei 430022, P.R. China

E-mail: chenlili1030@hust.edu.cn

E-mail: zldentist@hotmail.com

${ }^{*}$ Contributed equally

Key words: in vitro, biocompatibility, bioactivity, calcium silicate, bioceramic, endodontics

\section{Introduction}

The stem cell population in dental pulp possesses multilineage differentiation potential and the pulp vascular system participates in the reaction of dental pulp tissue to external stimulus, the initiation of dental pulp inflammation and pulp tissue repair (1). When sound dentin suffers damage, such as tooth wear, fracture, or caries, bacterial infection and the subsequent inflammatory response lead to damage of pulp tissue and impaired periapical tissue through blood circulation (2). Therefore, endodontic therapy has become a necessary option to preserve teeth by removing microorganisms, their by-products and residual necrotic tissue (3). However, the success rate of traditional endodontic therapy was only $70-80 \%$ over the past decade globally (4-6). The apical seal is important to improve the success rate in endodontic therapy; an excellent apical seal by root-end filling prevents the spread of dental pulp inflammation to the periapical tissue (7). In order to achieve a higher success rate in endodontic therapy, an ideal root-end filling material is required that possesses excellent root-end sealing capacity, good biocompatibility with surrounding cells/tissue, superior antibacterial properties and ability to promote tissue regeneration.

Mineral trioxide aggregate (MTA) has been used in root-end filling as calcium silicate-based bioceramic and displays better root apical sealing ability and higher success rates compared with conventional root-end filling materials, such as amalgam and intermediate restorative material (8-10). Furthermore, given its clinical effect in root-end filling in endodontic therapy, MTA has also been used in other endodontic application, such as pulp capping and regeneration and root perforation repair, and is currently considered as the gold standard in endodontics. As ProRoot MTA (Dentsply Sirona) has shown good clinical performance in endodontics, other calcium silicate-based bioceramics have been developed, including Bioaggregate (Innovative Bioceramix, Inc.), Biodentin (Septodont Holding) and iRoot BP/FS/SP (Innovative Bioceramix, Inc.) $(11,12)$.

The chemical constituents of these novel calcium silicate-based bioceramics are similar to that of MTA, but Bioaggregate, Biodentine and iRoot BP/BP Plus display better color stability than MTA because bismuth oxide is replaced by 
tantalum or zirconium oxide as a radiopacifier. Bioaggregate exhibits superior stable bond strength but inferior mechanical properties and bond strength in comparison with MTA. Biodentine shows increased mechanical strength and longer setting time as it does not contain calcium aluminate and calcium sulfate, which are present in MTA (13). iRoot BP/BP Plus, novel calcium silicate-based bioceramics applied in permanent root canal repair and filling, exhibit easier manipulation and faster setting time compared with MTA (14).

It is essential to clarify the effect and mechanism how these bioceramics influence the surrounding cells/tissue when used in endodontics. Numerous studies have investigated the biocompatibility and bioactivity of bioceramics in endodontics. Materials with good biocompatibility should not induce notable and continuous toxic effects on surrounding cells and tissue $(15,16)$. Biocompatibility can be defined as the interaction between implanted biomaterials and the associated tissue (17). Bioactive materials also induce apatite layer formation and biomineralization (18). Increased deposition of hydroxyapatite over time is observed when calcium silicate-based bioceramics are exposed to PBS, which suggests that these materials are bioactive (19-22). Bioceramics have been demonstrated to have excellent biocompatibility and lasting bioactivity during and after setting by the secretion of molecules. When calcium silicate-based bioceramics are applied in endodontics, the interaction between the materials and cells affect the biological behavior, such as proliferation, differentiation, migration and apoptosis $(23,24)$. Various types of cell are involved in changes of biological behavior when bioceramics are used in endodontics (Fig. 1). For example, calcium silicate-based bioceramics affect the biological behavior of dental pulp stem cells (DPSCs) in dental pulp capping, whereas osteoblasts/osteoclasts are influenced when bioceramics are applied as root-end filling material $(25,26)$. Despite the weakness of in vitro studies in mimicking the human body reaction to environmental stimuli and providing accurate results compared with animal or human studies, it is essential to investigate biocompatibility and bioactivity in vitro to clarify the mechanism underlying how calcium silicate-based bioceramics influence cell behavior. The present review focuses on in vitro biocompatibility and bioactivity when calcium silicate-based bioceramics are applied in endodontics. All information is summarized in Table I.

\section{Stem cells}

Mesenchymal stem cells (MSCs) derived from dental tissue originate from teeth and surrounding support tissue, possess similar biological characteristics to bone marrow-derived MSCs and differentiate into osteoblasts, adipocytes, chondrocytes and neural cells $(27,28)$. MSCs derived from dental tissue are capable of dentinogenesis or angiogenesis and secretion of growth factors, which influence behavior, such as proliferation, differentiation and mineralization (29). MSCs derived from dental tissue include DPSCs, periodontal ligament stem cells (PDLSCs), stem cells from human exfoliated deciduous teeth (SHED) and stem cells from apical papilla (SCAPs) that are involved in renewal and regeneration of dental tissue via the repair of injured dentin, root structure and the pulp-dentin complex (26,30,31) (Fig. 2). Calcium silicate-based bioceramics significantly promote attachment and survival of stem cells derived from dental tissue but their effects on biological behavior appear to be cell type-dependent (25). Several common markers are used to test the osteo/odontogenic and angiogenic potential of stem cells in the presence of calcium silicate-based bioceramics. For example, alkaline phosphatase (Alp) is a marker protein of mineralization and is associated with early osteo/odontogenic differentiation $(32,33)$. Collagen type I (COL1), osteocalcin (Ocn) and osteopontin (OPN) are expressed in the extracellular matrix and serve an important role in osteoblastic mineralization (34). Runt-related transcription factor 2 (Runx2) acts as a marker of osteogenesis in the early stage $(35,36)$, while Ocn functions in the late stage of osteogenic differentiation $(37,38)$. Regarding dentinogenesis, Runx 2 and its downstream molecule osterix (Osx), dentin sialoprotein and dentin sialophosphoprotein (DSPP) and its downstream molecule dentin matrix protein 1 (DMP1) $(39,40)$ are considered as protein markers closely associated with the formation and mineralization of odontoblasts.

DPSCs. MTA promotes the proliferation and survival of human DPSCs, bone marrow stromal/stem cells (BMSCs) and PDLSCs via the ERK signaling pathway (25), and also exhibit a positive effect on viability of human DPSCs (41). MTA at high concentrations (20 and $10 \mathrm{mg} / \mathrm{ml}$ ) is toxic to human DPSCs but MTA at low concentrations $(2.0,1.0,0.2$ and $0.1 \mathrm{mg} / \mathrm{ml})$ enhances viability of human DPSCs but has no effect lower concentrations (0.020 and $0.002 \mathrm{mg} / \mathrm{ml})$ (42). Similarly, undiluted MTA extract slightly increase survival of human DPSCs, while $1 / 2$ and 1/4 dilutions of MTA extract have no effect on cell viability (43). In addition, MTA at high concentrations $(20 \mathrm{mg} / \mathrm{ml})$ decreases proliferation of DPSCs under inflammatory conditions but has no effect at low concentrations (0.020 and $0.002 \mathrm{mg} / \mathrm{ml})$ (44). Moreover, various commercial MTA extracts, such as Angelus MTA (Angelus Dental Products Industry) and Root MTA (University of Tabriz, Iran), show similar effects on human DPSCs but were more biocompatible when applied at lower concentration (1:2) and longer exposure times compared with MTA. These results suggested that the biocompatibility of MTA is dependent on not only dosage but also exposure time (45). In terms of time-dependent biocompatibility of MTA, the cytotoxicity of MTA decreased over time and the viability and proliferation of human DPSCs increased following two aging cycles, which further supported the aforementioned time- and concentration-dependent effects of MTA (46). Moreover, the proliferation and viability of DPSCs decreased significantly when in direct contact with MTA for the first day but subsequently raised after three days (47). The initial cytotoxicity of MTA to growth and viability of DPSCs (47-49) may be partly ascribed to the relatively rough surface of biomaterials (50) or leakage of components such as bismuth oxide (51) and Al (52) and $\mathrm{Si}$ ions (53). Higher levels of $\mathrm{Si}$ ion concentrations from the $\mathrm{SiO}_{2}$ phase of materials may lead to hyperosmoticity and subsequently stimulates production of inflammatory cytokines (54). Furthermore, production of MTA during the hydration reaction and its exposure concentration may result in early slight cytotoxicity of MTA. Calcium hydroxide is produced when calcium silicate contained in MTA reacts with water and increases $\mathrm{pH}$ of the culture media $(55,56)$. 


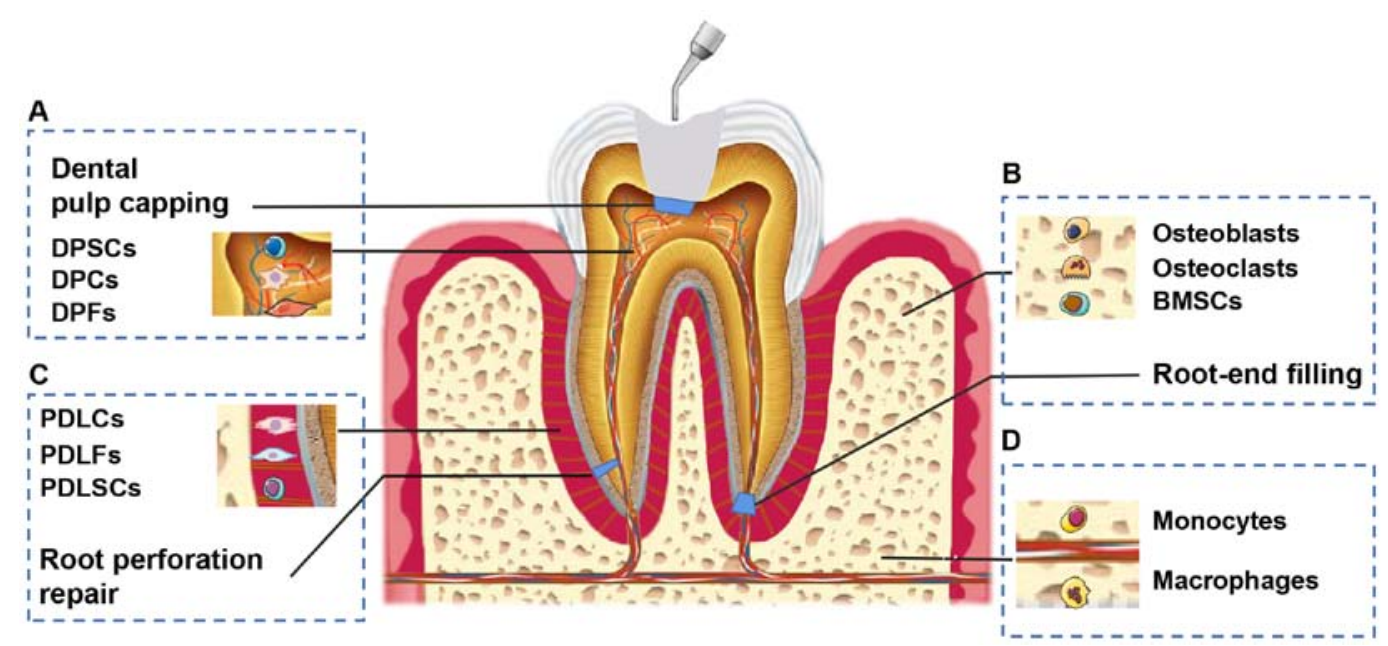

Figure 1. Application of calcium silicate-based bioceramics in endodontics and associated cells. Calcium silicate-based bioceramics affect the biological behavior of (A) DPSCs, DPCs and DPFs when used in dental pulp capping, (B) PDLSCs, PDLCs and PDLFs when applied in root perforation repair and (C) BMSCs, osteoblasts and osteoclasts when used as root-end filling material. (D) Immune cells, such as monocytes and macrophages, respond to implantation of calcium silicate-based biomaterials into tissue. DPSCs, dental pulp stem cells; DPCs, dental pulp cells; DPFs, dental pulp fibroblasts; PDLSCs, periodontal ligament stem cells; PDLCs, periodontal ligament cells; PDLFs, periodontal ligament fibroblasts; BMSCs, bone marrow stromal/stem cells.

Basic $\mathrm{pH}$ environment and release of inorganic salts induced by high concentrations of MTA significantly decreases cell proliferation (57). Furthermore, 24-h set MTA promotes viability of human DPSCs, whereas 1-h set MTA exhibits an inhibitory effect after 7 days, which suggests that incompletely solidified MTA is cytotoxic (58). The subsequent rise in cell viability may be caused by hydroxyapatite layer formation on the hydrated bioceramic surface (59) controlled continuous production of calcium, silica and phosphate ions from bioceramics along with alkaline $\mathrm{pH}$ in the later stage $(60,61)$. Regarding differentiation of human DPSCs, in the first week following induction with MTA in odontogenic differentiation medium, DPSCs began to change from spindle to rounded shape upon reaching confluency and then migrated to form clusters (62). DPSCs began to differentiate at day 7 (63) and mineralization was observed by Alizarin Red staining until day 21. Combination of MTA and odontogenic differentiation medium enhanced odontogenic differentiation of DPSCs but MTA extract-alone did not induce this (62). Treatment with MTA for 1 day affected more genes in uninduced DPSCs than in DPSCs induced by odontogenic differentiation medium, which suggested that MTA exhibits a greater stimulative effect on odontogenic differentiation of uninduced DPSCs compared with induced DPSCs (64). In addition, MTA at a concentration of $0.2 \mathrm{mg} / \mathrm{ml}$ displayed the strongest capacity to induce odontoblastic differentiation of human DPSCs via the p42/44 ERK signaling pathway (42). MTA-conditioned medium at the same concentration enhances the odonto/osteogenic capacity of DSPCs from inflammatory sites by activating the NF- $\mathrm{\kappa B}$ pathway, as shown by significantly upregulated odonto/osteoblastic gene expression levels, such as $A L P, R U N X 2, O S X, O C N$ and $D S P P(44)$. Consistent with the changes in genes associated with osteo/dentinogenic differentiation, MTA promotes mineralized nodule formation of human DPSCs $(65,66)$. Increased secretion of angiogenic factor VEGF has been detected in human DPSCs induced by MTA (63), which in turn affects viability and function of DPSCs (67). MTA contributes to dentin bridge formation in endodontics $(68,69)$. In addition,
MTA is applied in pulp capping because of its excellent bioactivity, which has been confirmed by the elongated shape of DPSCs, formation of collagen fibers and calcified deposition in the presence of MTA in a model simulating indirect pulp capping (70). In previous studies, accelerants, including 5\% $\mathrm{CaCl}_{2}$ and 2.5\% $\mathrm{Na}_{2} \mathrm{HPO}_{4}$, have been mixed with MTA to shorten setting time. Compared with MTA in the presence of distilled water, MTA in the presence of $5 \% \mathrm{CaCl}_{2}$ and $2.5 \%$ $\mathrm{Na}_{2} \mathrm{HPO}_{4}$ is more biocompatible and exhibits greater ability to promote odontoblastic differentiation of DPSC niches $(48,71)$. Propolis, a natural alternative endodontic material produced by honeybees from tree resin, also enhances the ability of MTA to promote odontogenic differentiation and mineralization of DPSCs via the ERK pathway (72).

Compared with human PDLSCs and tooth germ stem cells (TGSCs), human DPSCs exhibit better viability in the presence of both Biodentine and MTA (73). Moreover, Biodentine displays a superior ability to promote viability, adhesion and migration of human DPSCs compared with MTA. Human DPSCs spread on the surface of Biodentine show a spindle, polygonal and flattened morphology (74). Similar to MTA, high concentrations of Biodentine extract $(20 \mathrm{mg} / \mathrm{ml})$ exhibit slight cytotoxicity, whereas $0.2 \mathrm{mg} / \mathrm{ml}$ Biodentine enhances biological behaviors of human DPSCs, including cell proliferation, viability, migration, adhesion and mineralization formation. In addition, low concentrations of Biodentine $(0.2 \mathrm{mg} / \mathrm{ml})$ promote odontoblast differentiation and biomineralization of human DPSCs by activating ERK1/2 and JNK and attenuating the NF- $\kappa B$ pathway $(75,76)$. Increased Alp activity and dentin matrix protein expression levels have been observed in human DPSCs stimulated with Biodentine (75-78). Furthermore, Biodentine significantly increases calcium deposition (79) and enhances the production of Ocn and Runx2 in human DPSCs stimulated with lipopolysaccharide (LPS) although there is no change in $A L P$ expression levels (53). In terms of the inflammatory response, Biodentine does not affect high expression of IL- 6 and IL- 8 in DPSCs induced by LPS stimulation but decreases levels of the anti-inflammatory cytokine TGF- $\beta 1$ (53). 
Table I. In vitro studies of biocompatibility and bioactivity of calcium silicate-based bioceramics in endodontics.

\begin{tabular}{|c|c|c|c|c|}
\hline Bioceramic & Cell type & Subtype & Biocompatibility and bioactivity & References \\
\hline \multirow[t]{28}{*}{ MTA } & \multirow[t]{22}{*}{ Stem cells } & \multirow[t]{9}{*}{ DPSCs } & $\begin{array}{l}\text { Promotes proliferation and survival of human DPSCs, } \\
\text { BMSCs and PDLSCs via ERK signaling pathway }\end{array}$ & $(25)$ \\
\hline & & & Concentration- and time-dependent biocompatibility & $(42-45,48,49,99)$ \\
\hline & & & $\begin{array}{l}\text { Set MTA shows better biocompatibility than incompletely } \\
\text { set MTA }\end{array}$ & $(58)$ \\
\hline & & & $\begin{array}{l}\text { Cells change shape and migrate to form clusters during the } \\
\text { first week, and apparent mineralization at day } 21 \text { following } \\
\text { induction with MTA }\end{array}$ & $(62)$ \\
\hline & & & Begin to differentiate at day 7 following induction with MTA & $(63)$ \\
\hline & & & $\begin{array}{l}\text { Affect more genes in uninduced DPSCs than in DPSCs } \\
\text { induced by odontogenic differentiation medium }\end{array}$ & $(64)$ \\
\hline & & & $\begin{array}{l}\text { Promotes odonto/osteogenic differentiation via p42/44 ERK } \\
\text { and NF-кB pathways }\end{array}$ & $(42,44)$ \\
\hline & & & $\begin{array}{l}\text { Enhances formation of collagen fibers and mineralized } \\
\text { nodules }\end{array}$ & $(65,66,70)$ \\
\hline & & & Increases secretion of angiogenic factors, such as VEGF & $(63)$ \\
\hline & & \multirow[t]{2}{*}{ PDLSCs } & $\begin{array}{l}\text { Bioroot BC Sealer is more biocompatible than Endoseal } \\
\text { MTA and MTA Fillapex }\end{array}$ & $(100-102)$ \\
\hline & & & $\begin{array}{l}\text { Induces odonto/osteogenic differentiation by activating } \\
\text { NF- } \mathrm{B} \text { and MAPK pathways }\end{array}$ & $(103)$ \\
\hline & & \multirow[t]{3}{*}{ BMSCs } & $\begin{array}{l}\text { Respond more rapidly to MTA than human PDLSCs and } \\
\text { DPSCs }\end{array}$ & $(25)$ \\
\hline & & & $\begin{array}{l}\text { Rat BMSCs respond more rapidly to MTA than human } \\
\text { BMSCs }\end{array}$ & $(107-109)$ \\
\hline & & & $\begin{array}{l}\text { Induces proliferation and odonto/osteoblastic } \\
\text { differentiation in a dose-dependent manner via ERK and } \\
\text { JNK signalling pathways }\end{array}$ & $(25,110,111)$ \\
\hline & & \multirow[t]{2}{*}{ SHED } & $\begin{array}{l}\text { Enhances attachment, proliferation, migration and } \\
\text { odontogenic differentiation }\end{array}$ & $(125,126)$ \\
\hline & & & $\begin{array}{l}\text { Fresh mixed MTA and direct incubation with MTA induce } \\
\text { cytotoxicity }\end{array}$ & $(130)$ \\
\hline & & \multirow[t]{4}{*}{ SCAPs } & Concentration-/time-dependent biocompatibility & $(25,133-135,138)$ \\
\hline & & & $\begin{array}{l}\text { Induces odonto/osteogenic differentiation via NF- } \mathrm{NB} \text {, } \\
\text { p38 and ERK signaling }\end{array}$ & $(138-140,142)$ \\
\hline & & & $\begin{array}{l}\text { Increases expression of pro-inflammatory cytokines IL- } 1 \alpha \text {, } \\
\text { IL- } 1 \beta \text { and IL- } 6\end{array}$ & $(139)$ \\
\hline & & & $\begin{array}{l}\text { Increases expression of angiogenic genes VEGFA and } \\
\text { FIGF/VEGFD }\end{array}$ & $(134)$ \\
\hline & & \multirow[t]{2}{*}{ TGSCs } & $\begin{array}{l}\text { Biocompatible and increases release of PDGF, FGF-2 } \\
\text { and VEGF }\end{array}$ & $(73)$ \\
\hline & & & $\begin{array}{l}\text { Direct incubation with MTA inhibits viability and } \\
\text { odontogenic differentiation }\end{array}$ & $(151)$ \\
\hline & \multirow[t]{6}{*}{ Osteoblasts } & \multirow{2}{*}{$\begin{array}{l}\text { Primary } \\
\text { osteoblasts }\end{array}$} & Inhibit cell proliferation and differentiation & $(156-158)$ \\
\hline & & & $\begin{array}{l}\text { Biocompatible with primary osteoblasts cultured in 3D } \\
\text { culture system and promotes differentiation }\end{array}$ & $(166)$ \\
\hline & & MC3T3-E1 & $\begin{array}{l}\text { Promotes viability, osteoblastic differentiation and } \\
\text { by activating transcription factor } 6 \text { and endoplasmic } \\
\text { reticulum stress response }\end{array}$ & $(168-171)$ \\
\hline & & MG-63 & Cytotoxicity and inflammation decrease as material sets & $(167,174)$ \\
\hline & & Saos-2 & $\begin{array}{l}\text { Promote the adhesion, spreading, proliferation and } \\
\text { secretion of collagen }\end{array}$ & $(176,177)$ \\
\hline & & & Enhances osteogenic differentiation & $(178)$ \\
\hline
\end{tabular}


Table I. Continued.

\begin{tabular}{|c|c|c|c|c|}
\hline Bioceramic & Cell type & Subtype & Biocompatibility and bioactivity & References \\
\hline & \multirow[t]{2}{*}{ Osteoclasts } & \multirow[t]{2}{*}{ Osteoclasts } & $\begin{array}{l}\text { Inhibits bone resorption and osteoclast differentiation by } \\
\text { preventing migration and fusion of osteoclast precursors } \\
\text { via attenuation of the autophagic pathway }\end{array}$ & $(191,193,194)$ \\
\hline & & & Inhibit osteoclastogenesis dose-dependently & $(195,196)$ \\
\hline & \multirow[t]{11}{*}{ Fibroblasts } & \multirow[t]{3}{*}{ DPCs } & $\begin{array}{l}\text { More biocompatible with rat pulp cells (RPC-C2A) than } \\
\text { SuperEBA and Vitrebond }\end{array}$ & $(218)$ \\
\hline & & & $\begin{array}{l}\text { Promotes proliferation and odontogenic differentiation, } \\
\text { and decreases secretion of IL- } 1 \beta \text { and IL- } 6\end{array}$ & $(219,220)$ \\
\hline & & & Enhances expression of VEGF and angiogenin & $(222)$ \\
\hline & & \multirow[t]{2}{*}{ DPFs } & Less cytotoxic than $\mathrm{Ca}(\mathrm{OH})_{2}$ & $(232)$ \\
\hline & & & No cytotoxicity or genotoxicity & $(233)$ \\
\hline & & \multirow[t]{2}{*}{ PDLCs } & Inhibits proliferation, viability and differentiation & $(111,244)$ \\
\hline & & & Enhances calcification and BMP-2 expression & $(245)$ \\
\hline & & \multirow[t]{4}{*}{ PDLFs } & $\begin{array}{l}\text { Fresh MTA inhibits proliferation, attachment and } \\
\text { differentiation of PDLFs }\end{array}$ & $(250-253)$ \\
\hline & & & $\begin{array}{l}\text { More biocompatible than commonly used endodontic } \\
\text { materials }\end{array}$ & $(105,254-257)$ \\
\hline & & & Induces differentiation & $(105)$ \\
\hline & & & Concentration-/time-dependent biocompatibility & $(251,258-261)$ \\
\hline & \multirow[t]{8}{*}{$\begin{array}{l}\text { Immune } \\
\text { cells }\end{array}$} & \multirow[t]{2}{*}{$\begin{array}{l}\text { Monocytic } \\
\text { cells }\end{array}$} & $\begin{array}{l}\text { Biocompatible with THP1 cells and increases secretion of } \\
\text { cytokines by THP1 cells }\end{array}$ & $(272)$ \\
\hline & & & $\begin{array}{l}\text { Induces THP-1 polarization toward M2 phenotype by } \\
\text { activating } \mathrm{Axl} / \mathrm{Akt} / \mathrm{NF}-\kappa \mathrm{B} \text { signaling pathway }\end{array}$ & $(286)$ \\
\hline & & \multirow[t]{2}{*}{ Neutrophils } & Increases expression of IL- $1 \beta$ and IL- 8 & $(278)$ \\
\hline & & & $\begin{array}{l}\text { Enhances chemotaxis and chemokinesis by activation of } \\
\text { calcium-sensing receptors and downstream pathways }\end{array}$ & $(279)$ \\
\hline & & \multirow[t]{3}{*}{ Macrophages } & $\begin{array}{l}\text { Induces release and upregulates expression of neutrophil } \\
\text { chemotactic factor substances from macrophages and } \\
\text { mast cells }\end{array}$ & $(275-277)$ \\
\hline & & & Biocompatible & $(282-284)$ \\
\hline & & & $\begin{array}{l}\text { Increases expression of inflammatory cytokines and } \\
\text { induces M2 polarization in RAW } 264.7 \text { macrophages }\end{array}$ & $(282,285)$ \\
\hline & & Lymphocytes & No DNA breakage to human peripheral lymphocytes & $(287)$ \\
\hline \multirow[t]{9}{*}{ Bioaggregate } & Stem cells & BMSCs & Biocompatible & $(115)$ \\
\hline & Osteoblasts & MC3T3-E1 & $\begin{array}{l}\text { Shows no cytotoxicity and increases expression of COL1, } \\
\text { OCN and OPN }\end{array}$ & $(180)$ \\
\hline & Osteoclasts & Osteoclasts & $\begin{array}{l}\text { Similar ability to MTA to prevent migration and fusion to } \\
\text { inhibit bone resorption and differentiation via NF- } \mathrm{KB} \\
\text { signaling pathway }\end{array}$ & $(191-193)$ \\
\hline & \multirow[t]{6}{*}{ Fibroblasts } & \multirow[t]{3}{*}{ DPCs } & $\begin{array}{l}\text { Similar compatibility and ability to enhance odontogenic } \\
\text { differentiation by activation of MAPK signaling pathway } \\
\text { to MTA }\end{array}$ & $(223,224,226)$ \\
\hline & & & Superior to MTA in promoting cell adhesion and migration & $(225)$ \\
\hline & & & $\begin{array}{l}\text { Stronger potential to induce osteogenic differentiation } \\
\text { than MTA }\end{array}$ & $(223)$ \\
\hline & & \multirow[t]{2}{*}{ PDLCs } & Better biocompatibility than MTA & $(246)$ \\
\hline & & & $\begin{array}{l}\text { Promotes mineralization and osteogenic differentiation in } \\
\text { a concentration-/time-dependent manner via miR-146a }\end{array}$ & $(247)$ \\
\hline & & PDLFs & Comparable biocompatibility with MTA & $(262)$ \\
\hline Biodentine & Stem cells & DPSCs & $\begin{array}{l}\text { Superior to MTA in biocompatibility and mineralized nodule } \\
\text { formation }\end{array}$ & $(74,82,86)$ \\
\hline
\end{tabular}


Table I. Continued.

\begin{tabular}{|c|c|c|c|c|}
\hline Bioceramic & Cell type & Subtype & Biocompatibility and bioactivity & References \\
\hline & & & $\begin{array}{l}\text { Promotes osteo/odontogenic differentiation and } \\
\text { mineralization by activating ERK1/2 and JNK, and } \\
\text { attenuating NF- } \mathrm{KB} \text { pathways }\end{array}$ & $(53,75-78)$ \\
\hline & & & $\begin{array}{l}\text { No effect on expression of IL- } 6 \text { and IL- } 8 \text { but decreases } \\
\text { expression of TGF- } \beta\end{array}$ & (53) \\
\hline & & & More compatibility when stored in acid rather than saline & $(58)$ \\
\hline & & & $\begin{array}{l}\text { Slight toxicity and more odontogenic differentiation when } \\
\text { directly contacting DPSCs }\end{array}$ & $(49,77,80)$ \\
\hline & & & $\begin{array}{l}\text { Similar ability to improve expression of VEGF compared } \\
\text { with MTA }\end{array}$ & (49) \\
\hline & & PDLSCs & Similar dose-dependent biocompatibility to MTA & $(104)$ \\
\hline & & BMSCs & Promotes proliferation & $(116-118)$ \\
\hline & & & $\begin{array}{l}\text { Inferior to MTA in promoting proliferation and osteoblastic } \\
\text { differentiation }\end{array}$ & (119) \\
\hline & & SHED & Similar dose-dependent biocompatibility to MTA & $(126,126,128,129)$ \\
\hline & & & $\begin{array}{l}\text { Superior to MTA in promoting proliferation and calcified } \\
\text { matrix deposition }\end{array}$ & $(125,127)$ \\
\hline & & SCAPs & Similar biocompatibility to MTA & $(133,134,136)$ \\
\hline & & & $\begin{array}{l}\text { Induce odonto/osteogenic differentiation in dose-dependent } \\
\text { manner }\end{array}$ & $(138,139)$ \\
\hline & & & Superior to MTA in inducing odontoblastic differentiation & $(133,134,137)$ \\
\hline & & & $\begin{array}{l}\text { Similar capacity to enhance expression of pro-inflammatory } \\
\text { cytokines, such as IL- } 1 \alpha, \text { IL- } 1 \beta, \text { IL- } 6 \text { and TNF- } \alpha \text {, compared } \\
\text { with MTA }\end{array}$ & $(139)$ \\
\hline & & & Similar ability to promote expression of VEGFA and FGIF & $(134)$ \\
\hline & & TGSCs & Similar to MTA in biocompatibility and release of angiogenic & $(73)$ \\
\hline & \multirow[t]{4}{*}{ Osteoblasts } & $\begin{array}{l}\text { Primary } \\
\text { osteoblasts }\end{array}$ & Similar cytocompatibility to MTA & $(164,181)$ \\
\hline & & MG-63 & Similar cytocompatibility to MTA & $(182)$ \\
\hline & & MC3T3-E1 & Similar ability to promote calcification compared with MTA & $(183)$ \\
\hline & & Saos-2 & $\begin{array}{l}\text { Similar dose-dependent biocompatibility to MTA and } \\
\text { induces expression of ALP and mineralization }\end{array}$ & $(184)$ \\
\hline & Osteoclasts & Osteoclasts & $\begin{array}{l}\text { Lower inhibitory effect on differentiation and activity via } \\
\text { ERK } 1 / 2 \text { and NF- } \mathrm{B} \text { signaling pathways }\end{array}$ & $(197)$ \\
\hline & \multirow[t]{10}{*}{ Fibroblasts } & DPCs & $\begin{array}{l}\text { Biocompatible and promotes odontoblastic differentiation } \\
\text { and biomineralization }\end{array}$ & $(224,229)$ \\
\hline & & & Similar ability to MTA in increasing TGF- $\beta 1$ secretion & $(228)$ \\
\hline & & DPFs & $\begin{array}{l}\text { Similar biocompatibility to MTA in concentration-/time- } \\
\text { dependent manner }\end{array}$ & $(233,234)$ \\
\hline & & & $\begin{array}{l}\text { Affects differentiation in a concentration-dependent manner } \\
\text { by modulating TGF- } \beta 1 \text { secretion }\end{array}$ & $(228,234)$ \\
\hline & & & $\begin{array}{l}\text { More biocompatibility and less } \\
\text { inflammation compared with TheraCal }\end{array}$ & $(78,240,243)$ \\
\hline & & PDLCs & Similar biocompatibility to MTA & $(55,181)$ \\
\hline & & & Superior to MTA in terms of attachment and proliferation & $(181)$ \\
\hline & & PDLFs & Viability increases with time & $(261)$ \\
\hline & & & More cell aggregates on surface compared with MTA & $(267)$ \\
\hline & & & $\begin{array}{l}\text { Higher expression of Integrin } \beta 1 \text { and Vinculin compared } \\
\text { with MTA }\end{array}$ & $(268)$ \\
\hline & Immune cells & Monocytes & $\begin{array}{l}\text { Decreases adhesion of THP- } 1 \text { cells to endothelial cells, } \\
\text { migration and activation to macrophages }\end{array}$ & $(240)$ \\
\hline
\end{tabular}


Table I. Continued.

\begin{tabular}{|c|c|c|c|c|}
\hline Bioceramic & Cell type & Subtype & Biocompatibility and bioactivity & References \\
\hline & & & Similar biocompatibility compared with MTA & $(289)$ \\
\hline & & Macrophages & $\begin{array}{l}\text { No effect on activation and inflammatory response of } \\
\text { THP-1 macrophages }\end{array}$ & $(288)$ \\
\hline & & & $\begin{array}{l}\text { Greater inhibitory effect on expression of inflammatory } \\
\text { cytokines compared with MTA }\end{array}$ & $(183)$ \\
\hline \multirow[t]{8}{*}{$\begin{array}{l}\text { iRoot } \\
\text { BP Plus }\end{array}$} & Stem cells & DPSCs & $\begin{array}{l}\text { Greater ability to promote adhesion, migration and } \\
\text { mineralization than MTA }\end{array}$ & $(93)$ \\
\hline & & & $\begin{array}{l}\text { Similar ability to enhance formation of focal adhesions } \\
\text { and reorganization of the actin cytoskeleton compared with MTA }\end{array}$ & (94) \\
\hline & & $\mathrm{BMSCs}$ & $\begin{array}{l}\text { Enhances osteo/odontogenic differentiation via MAPK } \\
\text { pathway and autophagy }\end{array}$ & $(114)$ \\
\hline & & SHED & $\begin{array}{l}\text { Similar in promoting proliferation but superior in enhancing } \\
\text { migration, adhesion and osteogenetic differentiation }\end{array}$ & $(93)$ \\
\hline & Osteoblasts & $\begin{array}{l}\text { Primary } \\
\text { osteoblasts }\end{array}$ & More cytotoxic than MTA & $(185)$ \\
\hline & & MC3T3-E1 & $\begin{array}{l}\text { Improved viability under inflammatory acidic environment } \\
\text { compared with MTA }\end{array}$ & $(186)$ \\
\hline & Fibroblasts & DPCs & $\begin{array}{l}\text { Superior to MTA in proliferation, mineralization and } \\
\text { odontoblastic differentiation }\end{array}$ & $(226,230)$ \\
\hline & & & $\begin{array}{l}\text { Promotes migration and upregulates expression of focal } \\
\text { adhesion molecules via FGFR-mediated ERK 1/2, JNK and } \\
\text { Akt pathways }\end{array}$ & $(231)$ \\
\hline \multirow[t]{6}{*}{ iRoot FS } & Stem cells & DPSCs & Promotes proliferation, migration and osteogenic differentiation & $(97)$ \\
\hline & & & Superior to Biodentine in terms of proliferation and migration & (98) \\
\hline & & SCAPs & $\begin{array}{l}\text { Similar biocompatibility but stronger capacity to enhance } \\
\text { migration and osteo/odontogenesis via the Wnt/ } \beta \text {-catenin } \\
\text { pathway in comparison with MTA }\end{array}$ & $(147)$ \\
\hline & Osteoblasts & MC3T3-E1 & More biocompatible than iRoot BP Plus or MTA & $(187)$ \\
\hline & & MG63 & More biocompatible than iRoot BP Plus or MTA & $(188)$ \\
\hline & Fibroblasts & PDLCs & $\begin{array}{l}\text { Superior to Biodentine in cell viability, proliferation and } \\
\text { osteogenic differentiation }\end{array}$ & $(248)$ \\
\hline iRoot FM & Stem cells & SCAPs & $\begin{array}{l}\text { Induces proliferation and osteo/odontogenic differentiation } \\
\text { dose-dependently without affecting cell morphology }\end{array}$ & $(148)$ \\
\hline \multirow[t]{8}{*}{ iRoot SP } & Stem cells & TGSCs & Biocompatible & (152) \\
\hline & & & $\begin{array}{l}\text { Inferior to MTA in inducing odontogenic differentiation and } \\
\text { hard tissue deposition }\end{array}$ & (153) \\
\hline & Osteoblasts & MG63 & Biocompatible and enhances expression of COL1, OCN and BSP & (190) \\
\hline & Osteoclasts & Osteoclasts & $\begin{array}{l}\text { More cytotoxicity than MTA, but similar potential to inhibit } \\
\text { osteoclastogenesis }\end{array}$ & (200) \\
\hline & Fibroblasts & PDLCs & $\begin{array}{l}\text { Displays biocompatibility and enhances osteoblastic } \\
\text { differentiation via the integrin-mediated signaling pathway }\end{array}$ & $(249)$ \\
\hline & Immune cells & Macrophages & $\begin{array}{l}\text { More cytotoxic and primarily induces M1 macrophage } \\
\text { polarization compared with MTA }\end{array}$ & $(200)$ \\
\hline & & & $\begin{array}{l}\text { Similar ability to MTA in enhancing expression of } \\
\text { inflammatory cytokines in RAW } 264.7 \text { macrophages }\end{array}$ & $(200,282,285)$ \\
\hline & & & $\begin{array}{l}\text { Similar ability to shift balance of M1/M2 polarization to M2 } \\
\text { polarization compared with MTA }\end{array}$ & $(282,285)$ \\
\hline
\end{tabular}

MTA, mineral trioxide aggregate; DPSCs, dental pulp stem cells; DPCs, dental pulp cells; DPFs, dental pulp fibroblasts; PDLSCs, periodontal ligament stem cells; PDLCs, periodontal ligament cells; PDLFs, periodontal ligament fibroblasts; BMSCs, bone marrow stromal/stem cells. 
Stem cells
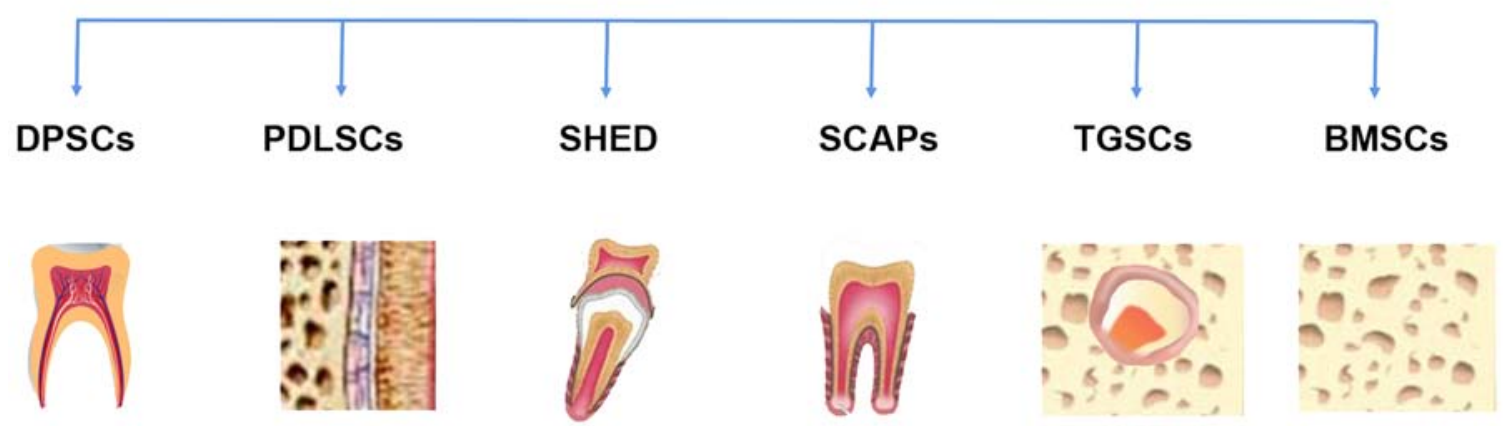

Figure 2. Stem cells involved in the interaction with calcium silicate-based bioceramics in endodontic application. (A) DPSCs. (B) PDLSCs. (C) SHEDs. (D) SCAPs. (E) TGSCs. (F) BMSCs. DPSCs, dental pulp stem cells; PDLSCs, periodontal ligament stem cells; SHED, stem cells from human exfoliated deciduous teeth; SCAPs, stem cells from apical papilla; TGSCs, tooth germ stem cells; BMSCs, bone marrow stromal/stem cells.

Although Biodentine medium is biocompatible with DPSCs, when in direct contact with DPSCs, Biodentine exhibits a slight toxic effect and delays closure of wound edges, which implies that direct contact between Biodentine and DPSCs leads to cell death or decreased proliferation $(80,81)$. However, unaltered expression levels of actin, tubulin and vimentin indicate that Biodentine neither induces apoptosis, inflammation and genotoxicity nor impairs cellular architecture. The inhibitory effect of Biodentine on cell proliferation and migration may result from the decreased space for cell growth in a direct culture model and prolonged cell doubling time (80). Similarly, other studies have observed that the viability of human DPSCs in direct contact with Biodentine is initially decreased $(49,77)$, which may be due to substantial calcium ion released from Biodentine in the first $3 \mathrm{~h}$ (82). Relatively large amounts of $\mathrm{Ca}$ and $\mathrm{Si}$ ions and the absence of $\mathrm{Sr}, \mathrm{Al}$ and $\mathrm{S}$ in Biodentine extract contribute to the biocompatibility of Biodentine (74). Considering the increased release of $\mathrm{Ca}$ and $\mathrm{Si}$ ions (83) and microstructural $(84,85)$ changes induced by acidic conditions, human DPSCs cultured in Biodentine stored in acidic environment display more spindle-shaped formation and higher adherent cell density compared with that in Biodentine stored in saline (58) Similar to MTA, Biodentine also increases gene expression levels of osteogenic and odontogenic markers, such as $O P N$ and $D S P P$ in human DPSCs when in direct contact with DPSCs $(49,77)$. However, Biodentine promotes odontogenic differentiation of DPSCs more significantly than osteogenic differentiation, as indicated by detection of expression levels of odontoblastic marker DSPP and osteogenic gene markers ALP, COLIAl and $O P N(80)$. Moreover, Biodentine promotes biomineralization and secretion of extracellular mineral matrix in human DPSCs cultured with osteogenic medium for 21 days (77) and induces more mineralized nodules in the osteogenic medium compared with MTA, suggesting that increased calcium ion release, along with a neutral $\mathrm{pH}$, promotes differentiation and mineralization of DPSCs and subsequently generates a greater number of structured dentin bridges (82). Similarly, when DPSCs are cultured with three-dimensional models, Biodentine induces higher viability compared with MTA. Furthermore, expression levels of COL1A1, ALP and DSPP in DPSCs on MTA and Biodentine are initially upregulated significantly and then decrease gradually until day 21 ; however, expression of $R U N X 2$ in three-dimensional cultures remains lower than that in control group (86). The reason for this may be that COL1A1, $A L P$ and $D S P P$ are associated with initiation of dentinogenesis and mineralization. Low expression levels of $R U N X 2$ contribute to odontoblast differentiation and cell maturation, whereas increased expression is observed during terminal odontoblast differentiation $(87,88)$. MTA and Biodentine stimulated angiogenesis by improving the expression levels of $V E G F$ in human DPSCs on day 14 (49). VEGF enhances the proliferation, migration, and tubulogenesis of endothelial cells close to microvessels, which regulates both vascularization and angiogenesis. Angiogenesis is a key factor for wound healing and tissue regeneration of damaged dental pulp (89-91). The pro-angiogenic capacity of bioceramics depends on dissolution products, such as $\mathrm{Si}, \mathrm{Mg}$ and $\mathrm{Ca}$ ions, which induce secretion of angiogenic factors from cells. Dissolution of calcium ions and subsequent precipitation reactions on the surface of bioceramics leads to vascular penetration and osteoblastic differentiation. Interconnections and pore size of the scaffold also influence the size and amount of the blood vessels, which are necessary for the vascularization of bioceramic material (92).

iRoot BP Plus promotes proliferation, attachment, migration and mineralization of DPSCs compared with MTA (93). Furthermore, iRoot BP Plus releases more Si ions than MTA, which may explain why iRoot BP Plus induces greater apatite formation. iRoot BP Plus and MTA promote stretched and highly organized stress fibre assembly of DPSCs, which is indicative of reorganization of the actin cytoskeleton. Moreover, iRoot BP Plus and MTA enhance phosphorylation of both Paxillin and focal adhesion kinase (FAK) and increase protein expression levels of Vinculin, FAK and Paxillin in human DPSCs (94); this is associated with the formation of focal adhesions (95). Cytoskeleton reorganization and focal adhesion formation is essential for cell adhesion and migration (96). These results confirmed that both iRoot BP Plus and MTA promote attachment and migration of human DPSCs. Likewise, iRoot FS enhances proliferation, migration, and osteoblastic differentiation of human DPSCs (97). Additionally, iRoot FS displays superior ability than Biodentine to promote proliferation and migration of human DPSCs on day 7. However, iRoot FS showed no significant effect on osteogenic differentiation on day 7 (98), which implied that iRoot FS affects proliferation and migration of human DPSCs and later influenced osteoblastic differentiation. A longer experimental 
observation period should be used to investigate the bioactivity of calcium silicate-based bioceramics on human DPSCs.

PDLSCs. MTA exhibits concentration-dependent cellular compatibility with human PDLSCs; MTA at higher dilution exhibits better biocompatibility with human PDLSCs (99). Due to the biological characteristics of MTA, other MTA-based endodontic materials have been developed, including Endoseal MTA (ES; Maruchi Co., Ltd.), Nanoceramic Sealer (NCS; B\&L Biotech USA, Inc.), Bioroot BC Sealer (BR; Septodont Holding) and MTA Fillapex (Angelus Dental Products Industry). Although human PDLSCs in the presence of these MTA-based bioceramics maintain high expression levels of MSC markers, including CD105, CD73 and CD90, the capacity of human PDLSCs to migrate, adhere and grow is higher when treated with BR at different concentrations compared with ES and NCS. ES and MTA Fillapex show cytotoxicity to human PDLSCs at 24, 48 and $72 \mathrm{~h}$ and give rise to worse cell attachment and spread, which may be caused by tungsten contained in MTA Fillapex (100-102). By contrast, $2 \mathrm{mg} / \mathrm{ml}$ MTA extract is the optimal concentration to markedly increase calcified nodule formation, Alp activity and odonto/osteogenic differentiation in human PDLSCs; these effects are mediated by activating NF- $\kappa$ B and MAPK signaling pathways (103). Likewise, $2 \mathrm{mg} / \mathrm{ml}$ Biodentine is the most biocompatible concentration to promote migration, attachment, and mineralization of human PDLSCs. Biodentine at low concentrations $(2.00,0.20$ and $0.02 \mathrm{mg} / \mathrm{ml})$ significantly enhances viability of human PDLSCs, while Biodentine at higher concentrations $(20 \mathrm{mg} / \mathrm{ml})$ exhibits cytotoxicity, which may be associated with high $\mathrm{pH}$ (104). High $\mathrm{pH}$ of Biodentine results in an increased concentration of iron and calcium ions in the extracellular environment (105). The inhibitory effect of Biodentine at high concentration $(20 \mathrm{mg} / \mathrm{ml})$ on the viability of human PDLSCs may be explained by increased or unbalanced ions levels, which generate a toxic effect on cells (106).

BMSCs. BMSCs are used as an in vitro model of MSCs associated with wound healing and tissue regeneration of alveolar bone. MTA promotes the adhesion and proliferation of human DPSCs, PDLSCs and BMSCs, which display an elongated morphology and are well-spread. Moreover, positive effects of MTA on proliferation are cell type-dependent (25). Human PDLSCs and DPSCs rapidly respond to MTA with significantly increased cell number by day 3, whereas human BMSCs stimulated with MTA show slow increase by day 5 (25). Furthermore, MTA promotes migration of human BMSCs significantly after $18 \mathrm{~h}$ and cells spread well on the surface of MTA after $24 \mathrm{~h}$. MTA increases proliferation of human BMSCs when incubated in normal medium, whilst the same phenomenon was delayed by 7 days when cultured in differentiation medium (107). When human BMSCs are cultured in osteogenic differentiation medium, MTA does not stimulate osteogenic differentiation by day 10 , as indicated by decreased mRNA and protein expression levels of osteogenic markers, such as $R U N X 2, O S X, M S X 2$ and $O C N$ (108). A positive effect of MTA on viability of rat BMSCs is observed up to day 7 , which is sooner than in human BMSCs. Simultaneously, MTA stimulates rat BMSC differentiation into osteoblast-like cells over 7 days, which is confirmed by enhanced ALP staining and upregulation of gene expression levels of bone morphogenetic protein $2(B M P-2), A L P$, bone sialoprotein $(B S P)$ and osteocalcin $(O C)$ (109). Low concentrations of MTA-conditioned media $(2.000,0.200,0.020$ and $0.002 \mathrm{mg} / \mathrm{ml})$ are not toxic to BMSCs and $0.02 \mathrm{mg} / \mathrm{ml} \mathrm{MTA}$ is the optimal concentration to upregulate odonto/osteogenic capacity of BMSCs originating from rat mandible; this finding was supported by enhanced Alp activity, calcified nodule formation and expression levels of odonto/osteoblastic genes in BMSCs, such as ALP, RUNX2, $O S X, O C N$ and $D S P P$. However, MTA at lower dilution inhibits the proliferation of BMSCs (110). Likewise, 1:5 MTA medium decreases viability and osteogenic differentiation of primary BMSCs from the hind limb of mice, as indicated by decreased von Kossa staining and low expression levels of $O C N$ and $B S P$ (111). Furthermore, tricalcium aluminate, a primary composite of MTA, contains aluminum and exhibits significant toxicity to rat BMSCs from femur and tibia bone marrow in vitro, whereas good tissue compatibility has been observed with tricalcium or dicalcium silicate (112). In addition, bismuth oxide in MTA is cytotoxic to human BMSCs (113). Therefore, the negative effect of MTA on the viability of BMSCs at high concentrations may partly be caused by tricalcium aluminate and bismuth oxide. Investigation of the mechanism underlying how MTA affects behavior of BMSCs has demonstrated that the ERK signaling pathway is associated with the positive effect of MTA on proliferation (25) and odonto/osteogenic differentiation of BMSCs. JNK signaling pathway is also involved in the odonto/osteogenic capacity of BMSCs induced by MTA (110). In addition, iRoot BP Plus promotes osteogenic/odontogenic differentiation of BMSCs via the MAPK signaling pathway and autophagy (114).

Bioaggregate is non-toxic to human BMSCs throughout a culture period of $24 \mathrm{~h}$ (115). Similarly, Biodentine promotes proliferation of rat (116) and human BMSCs $(117,118)$. Both Biodentine and MTA at high concentrations (1:2) show cytotoxicity to human BMSCs, while Biodentine at low concentrations (1:10 and 1:20) and long incubation periods exhibits an inferior ability to enhance proliferation and osteoblastic differentiation of human BMSCs compared with MTA (119). Moreover, Biodentine and MTA display an inhibitory effect on survival of human BMSCs in a concentration-dependent manner over 7 days but do not affect cell morphology (120). The cytotoxicity of Biodentine to human BMSCs may be ascribed to the calcium chloride contained in its liquid (121), which has been reported to exhibit less biocompatibility when added to MTA compared with MTA mixed with water (122). Therefore, Biodentine prepared following complete setting is more compatible with human BMSCs than MTA (120). High Alp activity with mineral deposits in rat BMSCs have been found in the presence of Biodentine after 12 days (116) but the capacity of Biodentine to induce osteogenic differentiation in human BMSCs is inferior to that of MTA $(117,118)$. MTA exhibits earlier and more pronounced calcium deposits than Biodentine (120), which may be explained by the fact that MTA produces high $\mathrm{pH}$ and Alp activity and promotes production of high concentration of Ca ions (123).

SHEDs. SHEDs originate from deciduous teeth and regenerate bone and dentin, but not dentin/pulp-like complexes as human DPSCs do (124). Due to the good porous microstructures in 
MTA or Biodentine, SHEDs attach and spread well on the surface of MTA and Biodentine, which helps SHEDs maintain mesenchymal properties in the presence of MTA or Biodentine with positive expression of CD105, CD90 and CD73 (125). Moreover, the capacity of SHEDs to adhere and proliferate is enhanced by MTA or Biodentine after $48 \mathrm{~h}$ (125). MTA and Biodentine exhibit a comparable ability to promote migration of SHEDs. In addition, the viability and proliferation of SHEDs cultured with $1 \mathrm{mg} / \mathrm{ml}$ MTA- or Biodentine-conditioned medium is similar to that of negative control during the whole incubation period, which implies that both MTA and Biodentine at $1 \mathrm{mg} / \mathrm{ml}$ are non-toxic to SHEDs (126). However, MTA shows greater potential to promote odontogenic differentiation compared with Biodentine (126), whereas Biodentine has better capability to promote proliferation and calcified matrix deposition in SHEDs than MTA $(125,127)$. Furthermore, Biodentine affects behavior of SHEDs in a concentration-dependent manner. Biodentine at low concentrations $(2.00,0.20$ and $0.02 \mathrm{mg} / \mathrm{ml})$ stimulates proliferation, viability and migration of SHEDs, whereas high concentrations of Biodentine $(20 \mathrm{mg} / \mathrm{ml})$ exhibit slight cytotoxicity to SHEDs. Changes in the concentration of Biodentine have no impact on the adhesion ability of SHEDs (128). Similarly, Biodentine at higher dilutions (1:16 and 1:32) is more effective in promoting proliferation, odontogenic differentiation and biomineralization of SHEDs, which may be because $\mathrm{Sr}$ and $\mathrm{Si}$ are gradually released from Biodentine as the concentration of Biodentine decreases over time (129). By contrast, fresh mixed MTA impairs the viability and migration of SHEDs and enhance apoptosis over 7 days. Furthermore, the cytotoxicity of MTA to SHEDs is more apparent when SHEDs directly contact MTA (130). The different results may be associated with the preparation of MTA. For example, freshly mixed MTA is frequently used in endodontics whereas bioceramic eluate or aged bioceramics were used in the aforementioned in vitro studies (86). However, the cytotoxicity of these bioceramics generally decreased as the bioceramic set and $\mathrm{pH}$ changed of medium over time. Freshly mixed MTA caused severe damage to cells due to the initially high concentration of calcium hydroxide and subsequent raise in $\mathrm{pH}$ to 12.5 after mixing for $3 \mathrm{~h}(131,132)$. Although iRoot BP Plus possesses a similar capacity to MTA in terms of SHEDs proliferation, it displays more prominent capacity to enhance adhesion, migration and osteogenesis of SHEDs compared with MTA (93).

SCAPs. Both MTA and Biodentine have been shown to promote the proliferation, odontoblastic differentiation and biomineralization of SCAPs over 14 days $(133,134)$. However, Schneider et al (135) found MTA induces early short-term proliferation of SCAPs over 5 days and promotes the migration of SCAPs after $6 \mathrm{~h}$. Saberi et al (136) discovered that the cytotoxicity of both complete set MTA and Biodentine to SCAPs decreased over time. By contrast, Miller et al (137) revealed that incompletely set MTA inhibits proliferation of SCAPs, whereas Biodentine promotes proliferation of SCAPs. The difference in results may be due to the method of cytotoxicity assessment, contact between cells and material, concentration of material and assessment time points. MTA affects survival of SCAPs in concentration-dependent manner. MTA at lower concentrations $(0.02,0.20$ and $2.00 \mathrm{mg} / \mathrm{ml})$ exhibits excellent biocompatibility with SCAPs; however, proliferation of SCAPs is inhibited and normal morphological cells disappeared when treated with MTA at higher concentrations (10 and $20 \mathrm{mg} / \mathrm{ml})$ (138). Low concentrations of MTA or Biodentine $(2.00,0.20$ and $0.02 \mathrm{mg} / \mathrm{ml})$ enhance Alp activity and osteoblastic/odontoblastic differentiation in SCAPs, while high concentrations of MTA or Biodentine $(20 \mathrm{mg} / \mathrm{ml})$ exhibit a negative effect $(138,139)$. MTA extract enhances the ability of osteogenic medium to induce mineralization and increase expression of mineralization-associated genes, such as Ocn (140). In comparison with MTA, SCAPs treated with Biodentine display greater odontoblastic differentiation, as demonstrated by positive alizarin red staining and expression of genes encoding DMP-1, DSPP, OCN and matrix extracellular phosphoglycoprotein $(133,134)$. Biodentine enhances expression of odontoblast specific marker DSPP, while MTA promotes osteoblastic differentiation of SCAPs by increasing expression of the osteoblastic marker integrin-binding sialoprotein (137). Both MTA and Biodentine enhance the secretion of pro-inflammatory cytokines, such as IL-1 $\alpha$, IL-1 $\beta$ and IL-6 (139), and MTA activates NF- $\kappa$ B signaling pathway, which affects the odonto/osteogenic differentiation of SCAPs $(141,142)$. In addition, p38 and ERK signaling pathways serve an essential role in odontoblastic/osteoblastic differentiation of SCAPs stimulated by MTA (138). MTA and Biodentine enhance the angiogenic potential of SCAPs; these bioceramics promote the expression of angiogenic genes in human SCAPs, such as VEGFA and c-fos induced growth factor $(F I G F)(134)$, which induce endothelial cell proliferation, migration and differentiation, and promote formation of endothelial tubules (143-146).

Compared with MTA, iRoot FS exhibits similar biocompatibility with human SCAPs but possesses markedly stronger capacity to enhance migration and osteo/odontogenesis differentiation of human SCAPs, and mineralized nodule formation via the Wnt/ $\beta$-catenin signaling pathway (147). iRoot FM at low concentrations $(0.5 \mathrm{mg} / \mathrm{ml})$ increases proliferation and osteo/odontoblastic differentiation of SCAPs, whereas there is no marked effect on SCAPs stimulated with iRoot FM at high concentrations (1.0 and $2.5 \mathrm{mg} / \mathrm{ml})$. Moreover, mineralized nodule formation and expression of $D M P-1$ and $A L P$ are enhanced by iRoot FM compared with $\mathrm{Ca}(\mathrm{OH})_{2}$. However, iRoot FM at different concentrations has no impact on morphology of SCAPs (148).

Human TGSCs. TGSCs, a popularized stem cell source derived from wisdom teeth, display MSC properties and can differentiate into endothelial or epithelial cells in dental tissue regeneration $(149,150)$. Consistent with human DPSCs and PLSCs, MTA and Biodentine exhibit no cytotoxicity to TGSCs (73). Nonetheless, viability and odontogenic differentiation of TGSCs are inhibited slightly when in direct contact with MTA, which has been confirmed by decreased numbers of attached cells and Alp activity (151). MTA and Biodentine induce angiogenesis of TGSCs by promoting the release of angiogenic growth factors (platelet-derived growth factor, fibroblast growth factor-2 and VEGF) and enhancing tube formation of human umbilical vein endothelial cells (73). Furthermore, iRoot SP exhibits good biocompatibility with human TGSCs and promote their attachment (152). iRoot SP 
possesses an inferior capacity to MTA in terms of inducing odontogenic differentiation of human TGSCs and hard tissue deposition; human TGSCs in the presence of MTA exhibit higher Alp activity and enhanced odontoblastic differentiation compared with those in the presence of iRoot SP (153).

\section{Osteoblasts/osteoclasts}

Restoration of bone tissue around teeth with lesions relies on the amount of, and balance between, osteoblasts and osteoclasts (154). When calcium silicate-based bioceramics are used in perforation repair, apical plugs in necrotic teeth or root-end filling in endodontics, the interaction between the bioceramics and osteoblasts in periapical tissue is key to inflammation control and wound repair of (155). The biological influence of calcium silicate-based bioceramics on osteoblasts/osteoclasts must be characterized.

Osteoblasts. Proksch et al (156) found that MTA impairs proliferation, osteogenic differentiation and extracellular matrix mineralization of primary human osteoblasts derived from the alveolar bone; this could be restored by addition of fluoride to MTA. Similarly, MTA inhibits proliferation and COL1 gene expression in bone marrow osteoblasts from rat femur (157). MTA inhibits proliferation and differentiation of rat primary calvarial osteoblasts, as demonstrated by decreased calcified nodule formation and osteoblastic differentiation (158). When primary osteoblasts are cultured with MTA, the highest ionic concentration in areas around MTA results in an inhibitory effect on primary osteoblasts in the central area (158). High dissolution rate of MTA and large release of calcium hydroxide from MTA contribute to highest ionic concentration in areas around MTA (159). Excess calcium concentration induces cell death by apoptosis or necrosis (160), whereas slight increases in extracellular $\mathrm{Ca}^{2+}$ concentration (161) and continuous low levels of calcium ion release, along with slower change in $\mathrm{pH}$, promote proliferation and differentiation of osteoblasts $(162,163)$. The decreased viability of primary human osteoblasts induced by MTA may be due to the cumulative effect of the release of toxic components, such as $\mathrm{Bi}$ and $\mathrm{Al}$ ions, following contact with bioceramic extract (164). These different results may be due to different methods and concentrations of bioceramics used in the experiments. MTA exhibit higher biocompatibility with osteoblasts cultured in three-dimensional culture systems and are attracted toward the material compared with cells cultured directly on materials or in extract. Increased percentage of mature osteoblasts or osteocytes with high expression levels of green fluorescent protein and osteogenic genes, including $A L P, B S P$ and $O S X$, in primary mouse mandibular osteoblasts demonstrates that MTA promotes differentiation of primary mouse osteoblasts in a three-dimensional cell culture model without differentiation medium, which is required for osteoblastic differentiation in a two-dimensional cell culture model $(165,166)$.

MTA exhibits minimal cytotoxicity to the human osteoblast MG-63 cell line (167). MTA promotes viability and increases mRNA expression levels of $C O L 1$ and $O C N$ in MC3T3-E1 cells induced by MTA, accompanied by enhancement of Alizarin Red-S staining and Alp activity, which suggests that MTA promotes bone matrix formation and mineralization of MC3T3-E1 cells (168-171). Moreover, when incubated on the surface of set MTA, a thick mineralized matrix layer covered with multilayered flat cells is observed in MC3T3-E1 cells after three weeks (169). The mechanism underlying MTA-induced osteoblastic differentiation, mineralization and bone matrix formation in MC3T3-E1 cells in vitro may be associated with the activation of activating transcription factor 6 by MTA and the subsequent endoplasmic reticulum stress response (170). Moreover, $\mathrm{Ca}, \mathrm{Si}$ and $\mathrm{P}$ ions released from MTA $(157,172)$ and alkaline $\mathrm{pH}$ value of MTA extract (171) contribute to the bioactivity of MTA. Alkaline $\mathrm{pH}$ neutralizes lactic acid, which dissolves mineralization of dentin, and promotes formation of hard tissue by activating alkaline phosphatase (173). MTA with high surface $\mathrm{pH}$ exhibits cytotoxicity to MG-63 cells initially (174); the inhibitory effect of MTA on viability of MG-63 cells weakens with the setting of MTA (174), which may be due to the fact that the expression of pro-inflammatory cytokines in MG-63 cells are increased by MTA during the first $24 \mathrm{~h}$ but decreased over time (167). Growth factor BMPs promote osteoblastic differentiation and biomineralization (175); the mixture of BMPs and MTA attenuates the cytotoxic effect of MTA to MG-63 cells and inflammation response of tissue to MTA (174). MTA promotes the adhesion, spreading, proliferation and collagen secretion in Saos-2 cells $(176,177)$. Moreover, MTA enhances osteogenic differentiation, Alp activity and calcified nodule formation in Saos-2 cell line (178). By contrast, Modareszadeh et al (179) reported that MTA does not affect survival and Alp activity in Saos-2 cell line. The inconsistency between these studies may due to differences in the preparation of MTA, experimental methods and assessment of Alp activity. Bioaggregate shows no cytotoxicity to MC3T3-E1 and markedly increases expression levels of mineral-associated genes, including COL1, OCN and $O P N$, in MC3T3-E1 cells compared with MTA (180).

Compared with MTA, Biodentine displays good cytocompatibility with primary human osteoblasts, indicated by enhancement of cell viability, attachment and proliferation $(164,181)$. Similar biocompatibility of MTA and Biodentine has been observed with human osteoblast-like cell line MG63; both enhance viability, adhesion and proliferation of MG63 cells, which may be because Biodentine and MTA have similar surface roughness, heterogeneous morphology and particle size (182). Biodentine and MTA both exhibit positive effects on viability and calcification of MC3T3-E1 cells (183). Biodentine and MTA show dose-dependent effects on viability of Saos-2 cells. Biodentine or MTA at lower concentrations (1:4 and 1:8) result in higher viability of Saos-2 cells. Furthermore, Biodentine stimulates proliferation and migration of Saos-2 cells and induces expression of $A L P$ and mineralization (184).

Compared with MTA, iRoot BP Plus induces greater cytotoxicity to primary human osteoblasts but is still considered as biocompatible because cell viability in the presence of iRoot BP Plus remained $>70 \%$ compared with that in the control group (185). When MTA or iRoot BP Plus is applied in acidic $\mathrm{pH}$ conditions, the secretion of $\mathrm{Ca}$ and $\mathrm{Si}$ ions is enhanced and apatite formation is decreased. However, cell attachment of MC3T3-E1 on these bioceramics is not affected significantly in an acidic environment. Furthermore, MTA decreases viability, whereas iRoot BP Plus increases survival of MC3T3-E1 cells, 
which suggests that, compared with MTA, iRoot BP Plus may be more suitable as root-end filling material under inflammatory acidic conditions when used in endodontics (186). By contrast, iRoot FS exhibits better biocompatibility with human osteoblast-like MC3T3-E1 and MG63 cells by promoting their attachment and proliferation $(187,186)$. iRoot FS shows better biocompatibility than MTA or iRoot BP Plus because certain toxic metal substances, such as bismuth (189), aluminium and manganese, are excluded in iRoot FS to enhance its compatibility. On the other hand, smaller particle size on the surface of iRoot FS results in higher cell attachment and subsequent proliferation (188). iRoot SP is non-cytotoxic to MG63 cells and enhances osteoblastic differentiation, which is beneficial to healing inflammatory periapical tissue (190).

Osteoclasts. The migration and fusion of osteoclast precursors is key to osteoclast formation. MTA and Bioaggregate inhibit bone resorption and osteoclast differentiation via preventing the migration and fusion of osteoclast precursors, including mouse bone marrow macrophages (191) and RAW264.7 macrophages (192-194). In addition, MTA inhibits osteoclastogenesis in a dose-dependent manner in the co-culture of mouse bone marrow cells with primary osteoblast cells. Furthermore, MTA suppresses expression of osteoprotegerin in primary osteoblast cells without affecting receptor activator of NF- $\mathrm{\kappa B}$ ligand (RANKL) expression levels $(195,196)$. Moreover, MTA solution at low concentration (20\%) impairs phosphorylation of c-Src, decreases expression levels of genes encoding MMP-9 and cathepsin $\mathrm{K}$ and disrupt formation of actin rings. MTA solution at high concentration (50\%) upregulate expression levels of Bim to increase apoptosis of osteoclasts (196). The mechanism underlying MTA-induced inhibition of osteoclastogenesis is associated with attenuation of the autophagic pathway, as demonstrated by decrease in autophagic vacuole and expression levels of autophagic genes and proteins (194). Bioaggregate inhibits osteoclastogenesis via the NF- $\mathrm{kB} / \mathrm{RANK}$ signaling pathway by decreasing expression levels of Rank, TNF receptor-associated factor $6, \mathrm{NF}-\mathrm{kB}$ and nuclear factor of activated T cells $1(192,193)$. Bioaggregate and MTA possess comparable ability to decrease osteoclast numbers and attenuate bone resorption (191). Bioaggregate or MTA inhibit osteoclast differentiation and bone resorption due to activation of autophagy in osteoclast differentiation; MTA inhibits osteoclast differentiation via inhibition of the autophagic pathway (194). Compared with MTA, Biodentine exhibits a lower inhibitory effect on osteoclast differentiation and activity of murine bone marrow macrophages by inhibiting ERK1/2 and NF- $\mathrm{kB}$ signaling pathways (197). Moreover, the inhibitory effect on osteoclast differentiation and activity of both MTA and Biodentine is similar to that of alendronate, which has been reported to prevent root resorption by inhibiting macrophages (197), which suggests the application of calcium silicate-based bioceramics as treatment to prevent root resorption in endodontics $(198,199)$. iRoot SP shows more cytotoxicity to RAW264.7 cells than MTA but possesses a similar ability to inhibit osteoclastogenesis (200). The aforementioned studies suggested that calcium silicate-based bioceramics attenuate osteoclast differentiation and the primary mechanism is associated with their bioactive elements. Bioactive elements contained in these bioceramics, such as $\mathrm{Ca}, \mathrm{Mg}, \mathrm{Si}$ and $\mathrm{Sr}$, enhance osteoblastic differentiation and suppress RANKL-induced osteoclastogenesis (201-204). A significant increase in $\mathrm{Si}$ and $\mathrm{Sr}$ ions has been observed in extracts of calcium silicate-based bioceramics $(192,205)$. Si ions enhance the viability, adhesion, differentiation, mineralization and angiogenesis of osteoblasts via the $\mathrm{Wnt} / \beta$-catenin and MAPK signaling pathways (206-210). Meanwhile, the effect of Si ion on surface roughness is characterized by increased adhesion and proliferation of human osteoblast cell lines (211). Furthermore, $\mathrm{Si}$ and $\mathrm{Sr}$ ions suppress RANKL-mediated osteoclastic differentiation and bone resorption by inhibiting expression levels of cathepsin $\mathrm{K}$, tartrate-resistant acid phosphatase and c-Fos $(205,212,213)$. In addition, $\mathrm{Si}$ and $\mathrm{Sr}$ ions create alkaline conditions, which neutralize lactic acid from osteoclasts and promotes accumulation of mineralized components of teeth $(214,215)$. Therefore, the bioactive elements exhibit synergistic effects on osteogenesis, osteoclastogenesis and angiogenesis of associated cells in endodontics (216).

\section{Dental pulp or periodontal ligament cells/fibroblasts (PDLC/Fs)}

Dental pulp or PDLC/Fs are associated with wound healing and tissue regeneration of dental or periapical tissue, respectively (217). When calcium silicate-based bioceramics are used in pulp capping, cells/fibroblasts from dental pulp are involved in interactions between cells and bioceramics. Cells/fibroblasts from periodontal ligament are affected by bioceramics applied in perforation repair or root-end filling. Numerous studies have investigated the effect on biocompatibility and bioactivity of cells/fibroblasts from dental pulp or periodontal ligament.

Dental pulp cells (DPCs). Compared with SuperEBA and Vitrebond, MTA exhibits decreased suppression of mitochondrial activity in the rat DPC RPC-C2A cell line (218). Furthermore, MTA significantly promotes proliferation, odontogenic differentiation and mineralization of human DPCs but inhibits secretion of $1 \mathrm{~L}-1 \beta$ and IL-6 $(219,220)$. In order to improve the bioactivity potential of MTA, the growth factor FGF-2 has been added to MTA to enhance its effect on proliferation and osteogenic differentiation of human DPCs (221). Set and fresh MTA display similar biocompatibility with human DPCs. In addition, MTA increases expression of the angiogenic factors VEGF and angiogenin (222). In comparison with MTA, Bioaggregate and Biodentine possess equal biocompatibility with human DPCs. Moreover, Bioaggregate, Biodentine and MTA enhance mRNA expression levels of ostogenic/odontogenic genes, such as ALP, OPN, OCN, DSPP and DMP-1, increase Alp activity and promote mineralization nodule formation due to activation of the MAPK signaling pathway induced by these calcium silicate-based bioceramics $(223,224)$. In addition, Bioaggregate exhibits superior capacity to MTA in terms of adhesion, attachment and migration of human DPCs (225). Moreover, compared with MTA, Bioaggregate induces enhanced mineralization and odontoblastic differentiation in human DPCs (226). In terms of osteogenic differentiation of human DPCs, Bioaggregate displays stronger potential than MTA (223). Both Biodentine and MTA promote mineralization by increasing secretion of TGF- $\beta 1$ from human DPCs, which mediates mineralization-associated cellular 
activity and subsequent dentin bridge formation $(227,228)$. Biodentine enhances cell proliferation, viability, migration, adhesion, odontoblastic differentiation and biomineralization of the immortalized murine DPC OD-21 cell line (229). iRoot BP Plus exhibits a higher proliferation rate of human DPCs compared with MTA during the whole culture period (230). Moreover, iRoot BP Plus promotes migration and upregulates the expression of focal adhesion molecules in human DPCs via the ERK 1/2, JNK and Akt signaling pathways (231). In addition, iRoot BP Plus possesses stronger potential than MTA to enhance the mineralization and odontoblastic differentiation of human DPCs (226).

Dental pulp fibroblasts (DPFs). Given that $\mathrm{Ca}(\mathrm{OH})_{2}$ and MTA are used in pulp capping, Kierat et al (232) compared cytotoxicity to human DPFs; MTA was less cytotoxic to human DPFs compared with $\mathrm{Ca}(\mathrm{OH})_{2}$. Likewise, Zakerzadeh et al (233) compared the biocompatibility of MTA and Biodentine with human DPFs; MTA and Biodentine did not display cytotoxicity or genotoxicity at $0-1,000 \mu \mathrm{g} / \mathrm{ml}$ concentration. Similarly, Biodentine does not influence the morphology, proliferation or cell integrity of human DPFs, but affects cell survival in a concentration- and time-dependent manner (234). Moreover, higher concentration of Biodentine suppress differentiation of DPFs by decreasing production of COL1 and TGF- $\beta 1$ (234), whereas Biodentine at lower concentrations stimulate TGF- $\beta 1$ secretion (228). Both TGF- $\beta 1$ and COL1 exhibit notable effects on collagen synthesis, mineralization and hard dental tissue generation $(228,235-237)$. TGF- $\beta 1$ and FGF-2 are also involved in proliferation, differentiation and migration of DPFs $(228,238,239)$. Giraud et al investigated the effect of Biodentine on injured human DPFs; Biodentine increased cellular survival and migration, as well as the secretion of FGF-2 and TGF- $\beta 1$ in lipoteichoic acid-stimulated and physically injured human DPFs. Moreover, injured DPFs exhibit decreased levels of pro-inflammatory cytokines, such as IL-6, and inflammatory cell recruitment in the presence of Biodentine compared with that in the presence of resin-containing TheraCal (240). TheraCal inhibits proliferation of human DPFs while Biodentine has no effect on proliferation of human DPFs. In addition, decreased release of pro-inflammatory cytokine IL-8 and higher mineralization have been observed in human DPFs induced by Biodentine compared with TheraCal (78). In addition, complement, particularly the C5a fragment, is involved in initiation of inflammation (241) and recruitment of DPSCs in regeneration (242). Due to the fact that C5a is produced by local DPFs when dental pulp is injured, Giraud et al compared several pulp capping materials and their effect on release of C5a in human DPFs. The results revealed that $\mathrm{C} 5 \mathrm{a}$ secretion of injured human DPFs was not affected by Biodentine, whereas TheraCal increased C5a secretion. Furthermore, compared with TheraCal, Biodentine significantly decreased recruitment of THP-1 cells involved in inflammation by affecting C5a/C5a receptor interactions (243). These results suggested that calcium silicate-based Biodentine affects the balance between initial pulp inflammatory reaction and subsequent pulp healing by affecting complement activation following pulp injury. Calcium silicate-based bioceramics shift the balance toward pulp healing, whereas resin-containing materials shift the balance toward pulp inflammation $(78,240)$.
PDLCs. Vidovic Zdrilic et al (111) found that MTA-conditioned medium promotes healing of injured periapical tissue in vivo, whereas MTA inhibits viability and biomineralization in mouse PDLCs in vitro. Eluate extract from MTA results in decreased viability and increased death of human PDLCs compared with those in a control group (medium-only) (244). By contrast, when human PDLCs are incubated with set MTA, MTA enhances mineralization and BMP-2 expression levels, which is caused by gradual production of $\mathrm{Ca}^{2+}$ from MTA and the interaction of BMP2/BMP-2 receptors in human PDLCs (245). These contradictory results may be due to different preparation methods of MTA. Set MTA releases calcium gradually and calcium at low concentrations stimulates cells mildly, whereas MTA-conditioned medium leads to immediate release of calcium at high concentrations; this may exert a negative effect on bioactivity of MTA to PDLCs. Compared with MTA, Bioaggregate displays better biocompatibility with human PDLCs, which may be due to the absence of aluminium in Bioaggregate. Moreover, the primary components of Bioaggregate, calcium silicate, calcium hydroxide and hydroxyapatite, stimulate proliferation of human PDLCs (246). In addition, Bioaggregate significantly increases mineralization in PDLCs in a concentration- and time-dependent manner. Furthermore, Bioaggregate enhances differentiation of PDLCs, particularly osteogenic differentiation, via microRNA-146a upregulation, as demonstrated by increased expression levels of $A L P, D M P 1$ and $B M P$ and decreased cementum protein 1 expression levels in PDLCs (247). In comparison with MTA, Biodentine exhibits equally good biocompatibility with human PDLCs $(55,181)$. Moreover, Biodentine displays greater potential in terms of attachment and proliferation of human PDLCs compared with MTA, which may be due to its hydroxyl apatite-like surface characteristics and greater release of calcium and silicon ions compared with MTA (181). Luo et al compared bioactivity of Biodentine and iRoot FS to human PDLCs and showed that both Biodentine and iRoot FS increased the adhesion of human PDLCs. iRoot FS possesses superior ability to Biodentine to promote viability, proliferation and osteoblastic differentiation of human PDLCs (248). In order to clarify the bioactivity of iRoot SP to human PDLCs, Chang et al investigated the biocompatibility and bioactivity of four root canal sealers: iRoot SP, Sealapex (Kerr Corporation), ARS (Dentsply-Sankin KK) and MTA Fillapex. The results revealed that all sealers were non-toxic to human PDLCs and increased Alp activity and formation of mineralization nodules. However, compared with Sealapex, an epoxy resin-based material, the other three sealers induced lower inflammatory response and enhanced osteogenic differentiation in PDLCs via the integrin-mediated signaling pathway (249).

PDLFs. Human PDLFs exhibit decreased proliferation rate when cultured on the surface of MTA compared with culturing on the surface of a coverslip (250); PDLFs on the surface of MTA have a rounded morphology with blunted extensions, while PDLFs on the surface of glass coverslips show good attachment and spreading (251). Balto investigated the effect of MTA surface characteristics on attachment of human PDLFs; human PDLFs did not attach to fresh MTA and the surface of cells appeared less smooth and exhibited more vacuoles. By contrast, human PDLFs on the surface of set MTA were 
round and flattened with smooth surfaces and attached well to MTA (252). Similarly, Bonson et al reported that human PDLFs exposed to washed MTA possess greater proliferation capacity those exposed to fresh MTA. Moreover, compared with fresh MTA, washed MTA exhibits stronger potential to induce osteogenic differentiation of human PDLFs (253). Compared with other endodontic materials, such as Diaket (ESPE; 3M), Super-EBA (Harry J Bosworth Company) and amalgam, MTA also displays better biocompatibility with human PDLFs and does not induce apoptosis and necrosis of human PDLFs (254-257). Compared with these other materials in root perforation models in vitro, MTA also results in higher viability in human PDLFs and induces mRNA expression levels of COL1 and RUNX2 in human PDLFs, which suggests that MTA has potential to induce osteogenic differentiation of PDLFs, which is key for periodontal regeneration (105). Likewise, MTA-conditioned medium at low concentrations $(0.5,5.0$ and $50.0 \mu \mathrm{g} / \mathrm{ml})$ possesses superior capacity to formocresol and ferric sulphate in maintaining the viability of human PDLFs, whereas MTA at higher concentrations $(5,000 \mu \mathrm{g} / \mathrm{ml})$ shows slight cytotoxicity to human PDLFs $(258,259)$. Bioaggregate displays biocompatibility with human PDLFs comparable to that of MTA, whereas viability of human PDLFs in the presence of Biodentine is slightly decreased compared with MTA (260-262). By contrast, Akbulut et al (263) reported that Biodentine possesses better biocompatibility with human PDLFs. This discrepancy may be associated with chemical composition of the material, assessment time point and surface characteristics. In terms of chemical composition, calcium chloride used in the liquid of Biodentine as an accelerator decreases the setting time (264) and results in early production of calcium hydroxide, which contributes to relatively decreased cell survival after $24 \mathrm{~h}$ in the presence of Biodentine (265). Moreover, zirconium oxide in Biodentine is non-toxic to murine PDLFs, but bismuth oxide in MTA has no impact on cell growth (266). MTA supports higher cell viability during the first $24 \mathrm{~h}$ but decreases cell viability to $80 \%$ later $(251,260)$. Biodentine maintains lower cell viability during the first $24 \mathrm{~h}$ but viability increases gradually over time (261). Human PDLFs attach well to the surfaces of both MTA and Biodentine and maintain their original morphology. Nevertheless, more cell aggregates have been observed on the surface of Biodentine, whereas human PDLFs tend to show greater spread and elongation on MTA (267). Moreover, expression levels of Integrin $\beta 1$ and Vinculin, which are associated with focal contacts between human PDLFs and bioceramics, are higher in human PDLFs treated with Biodentine than in those treated with MTA, which suggests that the surface characteristics of Biodentine promote the adhesion and survival of human PDLFs more strongly compared with MTA (268).

\section{Immune cells}

Immune cells, such as monocytes and macrophages, respond immediately when biomaterials are placed into tissue, which causes the initial inflammatory response and tissue healing. Macrophages release pro-inflammatory cytokines in the beginning of an acute inflammatory response, such as TNF- $\alpha$, IL-1 and IL-12, but release anti-inflammatory cytokines during regeneration and healing of tissue, such as IL-4, which contributes to the production of fibronectin (269-271). MTA displays detectable, but not statistically significant, cytotoxicity to human monocytic cell line THP1 and alters secretion of inflammatory cytokines (272). In addition, macrophages and mast cells participate in leukocyte recruitment and extravasation via secretion of inflammatory cytokines that regulate inflammation control and tissue healing in pulpitis and apical periodontitis $(273,274)$. Moreover, neutrophil chemotactic factor is induced from macrophages and mast cells by MTA; the upregulation of these neutrophil chemotactic factor substances participates in migration and accumulation of neutrophils, monocytes and lymphocytes (275-277). Similarly, Cavalcanti et al (278) found that MTA increases secretion of IL- 8 and IL-1 $\beta$, which supports the migration of human neutrophils. Chang et al (279) discovered that MTA enhances migration of immune cells, which is regulated by calcium-sensing receptors and the PI3K pathway for chemotaxis, as well as the $\mathrm{Ca}^{2+}$-calmodulin-dependent MLCK pathway for chemokinesis.

M1/M2 macrophage polarization is associated with the inflammatory response and subsequent tissue regeneration following biomaterial implantation $(270,280,281)$. Tu et al found that iRoot SP induces greater cytotoxicity to RAW264.7 macrophages than MTA. Furthermore, both MTA and iRoot SP induce expression of pro-inflammatory cytokines without inducing osteoclastogenesis in RAW264.7 macrophages. In addition, MTA primarily induces M2 macrophage polarization, whereas iRoot SP induces M1 macrophage polarization (200). Both MTA and iRoot SP are non-toxic to RAW264.7 cells (282). Moreover, MTA does not affect the viability and adherence of M1 and M2 macrophages isolated from mice $(283,284)$. MTA and iRoot SP reinforce expression of inflammatory cytokines in RAW264.7 cells. Furthermore, MTA and iRoot SP possess equal capacity to stimulate M1/M2 macrophage polarization but greater M2 macrophage polarization is induced, which implies that calcium silicate-based bioceramics shift M1/M2 polarization balance to M2 macrophage polarization under inflammatory conditions $(282,285)$. Yeh et al reported that MTA induces THP-1 cells toward $\mathrm{M} 2$ polarization by activating the $\mathrm{Axl} / \mathrm{Akt} / \mathrm{NF}-\kappa \mathrm{B}$ signaling pathway. MTA promotes tissue regeneration and wound healing via M2 macrophage polarization (286). MTA does not induce DNA breakage of human peripheral lymphocytes, which is the first step in carcinogenesis. This suggests that MTA exhibits no potential carcinogenic risk when used in endodontics (287).

Compared with other pulp capping materials, such as TheraCal and Xeno III, Biodentine decreases migration and adhesion of THP-1 cells to endothelial cells and inhibits their activation to macrophages in vitro (240). In addition, Biodentine does not stimulate expression of inflammation-associated enzymes in vitro, such as prostaglandin E2 and thromboxane (288). Compared with MTA, Biodentine displays a more notable inhibitory effect on mRNA and protein expression levels of inflammatory cytokines in RAW264.7 macrophages (183). Biodentine is biocompatible with immune cells, which is consistent with another study that demonstrated that Biodentine exhibits similar biocompatibility with human monocytes compared with MTA (289). 


\section{Conclusion}

There have been numerous studies on the in vitro biocompatibility and bioactivity of calcium silicate-based bioceramics in endodontics $(16,79,147,192)$. MTA has been investigated most thoroughly and is considered the gold standard. However, compared with MTA, there are not enough studies to assess the biocompatibility and bioactivity of other calcium silicate-based bioceramics, such as Bioaggregate, Biodentine and iRoot BP/FS/SP, in endodontics. Therefore, further studies are required. Results from various in vitro models are inconsistent due to several reasons. Considering the discrepancy in cell types and methods to prepare the sample and evaluate the effect of MTA, it is difficult to compare the results and conclusions from different studies. Firstly, (patho-) physiological and anatomical differences between cells may lead to discrepancies in results. Secondly, experimental procedures and associated assessment criteria are distinctive so it is difficult to compare results directly and apply them to use in humans. It is essential to establish a well-defined gold standard model, experimental procedures and evaluation criteria to overcome this. Although calcium silicate-based bioceramics display excellent biocompatibility and bioactivity, the combined use of calcium silicate-based bioceramics with other materials/procedures improves efficiency of the calcium silicate-based bioceramics in endodontics. For example, the addition of TGF- $\beta 1$ and VEGF to bioceramics displays better biocompatibility with human DPSCs and promotes formation of dentin bridge in rat pulp capping compared with MTA (290). Further studies are required to determine the effects of combined bioceramics.

\section{Acknowledgements}

Not applicable.

\section{Funding}

The present review was supported by grants from the National Key R\&D Program of China (grant no. 2017YFC1104301) and National Natural Science Foundation of China (grant no. 81700955).

\section{Availability of data and materials}

Not applicable.

\section{Authors' contributions}

WS conceived and wrote the manuscript. WS and SL contributed to data acquisition, analysis and interpretation. QT made substantial contributions to conception and design. LC and ZY critically revised the manuscript. Data sharing is not applicable. All authors read and approved the final manuscript.

\section{Ethics approval and consent to participate}

Not applicable.

\section{Patient consent for publication}

Not applicable.

\section{Competing interests}

The authors declare they have no competing interests.

\section{References}

1. Liu H, Gronthos S and Shi S: Dental pulp stem cells. Methods Enzymol 419: 99-113, 2006.

2. Heyeraas KJ and Kvinnsland I: Tissue pressure and blood flow in pulpal inflammation. Proc Finn Dent Soc 88 (Suppl 1): S393-S401, 1992.

3. Mohammadi Z and Dummer PMH: Properties and applications of calcium hydroxide in endodontics and dental traumatology. Int Endod J 44: 697-730, 2011.

4. Siew K, Lee AH and Cheung GS: Treatment outcome of repaired root perforation: A systematic review and meta-analysis. J Endod 41: 1795-1804, 2015.

5. Juneja $P$ and Kulkarni S: Clinical and radiographic comparison of biodentine, mineral trioxide aggregate and formocresol as pulpotomy agents in primary molars. Eur Arch Paediatr Dent 18: 271-278, 2017.

6. Suhag K, Duhan J, Tewari S and Sangwan P: Success of direct pulp capping using mineral trioxide aggregate and calcium hydroxide in mature permanent molars with pulps exposed during carious tissue removal: 1-year follow-up. J Endod 45: 840-847, 2019.

7. Gutmann JL and Pitt Ford TR: Management of the resected root end: A clinical review. Int Endod J 26: 273-283, 1993.

8. Abusrewil SM, McLean W and Scott JA: The use of Bioceramics as root-end filling materials in periradicular surgery: A literature review. Saudi Dent J 30: 273-282, 2018.

9. Torabinejad M, Watson TF and Pitt Ford TR: Sealing ability of a mineral trioxide aggregate when used as a root end filling material. J Endod 19: 591-595, 1993.

10. Asgary S, Eghbal MJ and Parirokh M: Sealing ability of a novel endodontic cement as a root-end filling material. J Biomed Mater Res A 87: 706-709, 2008.

11. Parirokh M, Torabinejad M and Dummer PMH: Mineral trioxide aggregate and other bioactive endodontic cements: An updated overview-part I: Vital pulp therapy. Int Endod J 51: 177-205, 2018.

12. Torabinejad M, Parirokh M and Dummer P: Mineral trioxide aggregate and other bioactive endodontic cements: An updated overview - part II: Other clinical applications and complications. Int Endod J 51: 284-317, 2018.

13. Majeed A and AlShwaimi E: Push-out bond strength and surface microhardness of calcium silicate-based biomaterials: An in vitro study. Med Princ Pract 26: 139-145, 2017.

14. Song W, Sun W, Chen L and Yuan Z: In vivo biocompatibility and bioactivity of calcium silicate-based bioceramics in endodontics. Front Bioeng Biotechnol 8: 580954, 2020.

15. Rodriguez-Lozano FJ, Lopez-Garcia S, Garcia-Bernal D, Sanz JL, Lozano A, Pecci-Lloret MP, Melo M, Lopez-Gines C and Forner L: Cytocompatibility and bioactive properties of the new dual-curing resin-modified calcium silicate-based material for vital pulp therapy. Clin Oral Investig: Feb 27, 2021 (Epub ahead of print).

16. Garrido M, Morales D, Saldias MP, Fernandez C, Villalobos V, Cerda $\mathrm{O}$ and Caceres M: Cellular response of human apical papilla cells to calcium hydroxide and tricalcium silicate-based cements. BMC Oral Health 21: 106, 2021.

17. Lemons JE: Ceramics: Past, present, and future. Bone 19 (Suppl 1): 121S-128S, 1996.

18. Hench LL and Wilson J: Surface-active biomaterials. Science 226: 630-636, 1984.

19. Grech L, Mallia B and Camilleri J: Investigation of the physical properties of tricalcium silicate cement-based root-end filling materials. Dent Mater 29: e20-e28, 2013.

20. Shokouhinejad N, Nekoofar MH, Razmi H, Sajadi S, Davies TE, Saghiri MA, Gorjestani $\mathrm{H}$ and Dummer PM: Bioactivity of EndoSequence root repair material and bioaggregate. Int Endod J 45: 1127-1134, 2012.

21. Han L, Okiji T and Okawa S: Morphological and chemical analysis of different precipitates on mineral trioxide aggregate immersed in different fluids. Dent Mater J 29: 512-517, 2010.

22. Camilleri J: Characterization and hydration kinetics of tricalcium silicate cement for use as a dental biomaterial. Dent Mater 27: 836-844, 2011 
23. Zhao $\mathrm{W}$, Chang $\mathrm{J}$ and $\mathrm{Zhai} \mathrm{W}$ : Self-setting properties and in vitro bioactivity of $\mathrm{Ca}_{3} \mathrm{SiO}_{5} / \mathrm{CaSO}_{4} \cdot 1 / 2 \mathrm{H}_{2} \mathrm{O}$ composite cement. J Biomed Mater Res A 85: 336-344, 2008.

24. Zhao W, Wang J, Zhai W, Wang Z and Chang J: The self-setting properties and in vitro bioactivity of tricalcium silicate. Biomaterials 26: 6113-6121,2005.

25. Chen I, Salhab I, Setzer FC, Kim S and Nah HD: A new calcium silicate-based bioceramic material promotes human osteo- and odontogenic stem cell proliferation and survival via the extracellular signal-regulated kinase signaling pathway. J Endod 42 480-486, 2016

26. Morsczeck $C$ and Reichert TE: Dental stem cells in tooth regeneration and repair in the future. Expert Opin Biol Ther 18 187-196, 2018

27. Aydin S and Sahin F: Stem cells derived from dental tissues. Adv Exp Med Biol 1144: 123-132, 2019.

28. Rodriguez-Lozano FJ, Bueno C, Insausti CL, Meseguer L, Ramirez MC, Blanquer M, Marin N, Martinez S and Moraleda JM: Mesenchymal stem cells derived from dental tissues. Int Endod J 44: 800-806, 2011.

29. Rombouts C, Giraud T, Jeanneau C and About I: Pulp Vascularization during tooth development, regeneration, and therapy. J Dent Res 96: 137-144, 2017.

30. Murray PE, Garcia-Godoy F and Hargreaves KM: Regenerative endodontics: A review of current status and a call for action. J Endodont 33: 377-390, 2007.

31. Orti V, Collart-Dutilleul PY, Piglionico S, Pall O, Cuisinier F and Panayotov I: Pulp regeneration concepts for nonvital teeth: From tissue engineering to clinical approaches. Tissue Eng Part B Rev 24: 419-442, 2018.

32. Sugawara Y, Suzuki K, Koshikawa M, Ando M and Iida J: Necessity of enzymatic activity of alkaline phosphatase for mineralization of osteoblastic cells. Jpn J Pharmacol 88: 262-269, 2002.

33. Cormier C: Markers of bone metabolism. Curr Opin Rheumatol 7: 243-248, 1995

34. Rodan GA and Noda M: Gene expression in osteoblastic cells. Crit Rev Eukaryot Gene Expr 1: 85-98, 1991.

35. Camilleri S and McDonald F: Runx2 and dental development. Eur J Oral Sci 114: 361-373, 2006.

36. Karsenty G and Wagner EF: Reaching a genetic and molecular understanding of skeletal development. Dev Cell 2: 389-406, 2002.

37. Rathinam E, Rajasekharan S, Chitturi RT, Martens L and De Coster P: Gene expression profiling and molecular signaling of dental pulp cells in response to tricalcium silicate cements: A systematic review. J Endod 41: 1805-1817, 2015.

38. Bai Y, Bai Y, Matsuzaka K, Hashimoto S, Kokubu E, Wang X and Inoue T: Formation of bone-like tissue by dental follicle cells co-cultured with dental papilla cells. Cell Tissue Res 342 221-231, 2010

39. Gibson MP, Zhu Q, Wang S, Liu Q, Liu Y, Wang X, Yuan B, Ruest LB, Feng JQ, D'Souza RN, et al: The rescue of dentin matrix protein 1 (DMP1)-deficient tooth defects by the transgenic expression of dentin sialophosphoprotein (DSPP) indicates that DSPP is a downstream effector molecule of DMP1 in dentinogenesis. J Biol Chem 288: 7204-7214, 2013.

40. Lee SK, Lee KE, Jeon D, Lee G, Lee H, Shin CU, Jung YJ, Lee SH, Hahn SH and Kim JW: A novel mutation in the DSPP gene associated with dentinogenesis imperfecta type II. J Dent Res 88: 51-55, 2009.

41. Chang CC, Yeh CL, Chang HH, Kuo YF, Huang PY and Lin CP: Effect of different zinc concentrations on partially-stabilized cement for vital pulp therapy. J Formos Med Assoc 118: $1610-1615,2019$

42. Zhao X, He W, Song Z, Tong Z, Li S and Ni L: Mineral trioxide aggregate promotes odontoblastic differentiation via mitogen-activated protein kinase pathway in human dental pulp stem cells. Mol Biol Rep 39: 215-220, 2012.

43. Tomas-Catala CJ, Collado-Gonzalez M, Garcia-Bernal D, Onate-Sanchez RE, Forner L, Llena C, Lozano A, Castelo-Baz P, Moraleda JM and Rodriguez-Lozano FJ: Comparative analysis of the biological effects of the endodontic bioactive cements MTA-Angelus, MTA Repair HP and NeoMTA Plus on human dental pulp stem cells. Int Endod J 50 Suppl 2: e63-e72, 2017.

44. Wang Y, Yan M, Fan Z, Ma L, Yu Y and Yu J: Mineral trioxide aggregate enhances the odonto/osteogenic capacity of stem cells from inflammatory dental pulps via NF- $\kappa \mathrm{B}$ pathway. Oral Dis 20: 650-658, 2014.
45. Jaberiansari Z, Naderi S and Tabatabaei FS: Cytotoxic effects of various mineral trioxide aggregate formulations, calcium-enriched mixture and a new cement on human pulp stem cells. Iran Endod J 9: 271-276, 2014

46. Niu LN, Watson D, Thames K, Primus CM, Bergeron BE, Jiao K, Bortoluzzi EA, Cutler CW, Chen JH, Pashley DH and Tay FR: Effects of a discoloration-resistant calcium aluminosilicate cement on the viability and proliferation of undifferentiated human dental pulp stem cells. Sci Rep 5: 17177, 2015.

47. Mohamed DA, Abdelfattah MI and Aboulezz EH: The effect of three different biomaterials on proliferation and viability of human dental pulp stem cells (In-vitro Study). Open Access Maced J Med Sci 5: 657-663, 2017.

48. Kulan P, Karabiyik O, Kose GT and Kargul B: The effect of accelerated mineral trioxide aggregate on odontoblastic differentiation in dental pulp stem cell niches. Int Endod J 51: 758-766, 2018.

49. Youssef AR, Emara R, Taher MM, Al-Allaf FA, Almalki M, Almasri MA and Siddiqui SS: Effects of mineral trioxide aggregate, calcium hydroxide, biodentine and Emdogain on osteogenesis, Odontogenesis, angiogenesis and cell viability of dental pulp stem cells. BMC Oral Health 19: 133, 2019.

50. Minyong W, He L, Shenglin L and Man Q: Effects of mineral trioxide aggregate on the proliferation and differentiation of human pulp cells from primary and permanent teeth. Hua Xi Kou Qiang Yi Xue Za Zhi 33: 75-79, 2015 (In Chinese).

51. Camilleri J, Montesin FE, Papaioannou S, McDonald F and Pitt Ford TR: Biocompatibility of two commercial forms of mineral trioxide aggregate. Int Endod J 37: 699-704, 2004.

52. Demirkaya K, Can Demirdöğen B, Öncel Torun Z, Erdem O, Cetinkaya $S$ and Akay C: In vivo evaluation of the effects of hydraulic calcium silicate dental cements on plasma and liver aluminium levels in rats. Eur J Oral Sci 124: 75-81, 2016.

53. Chung M,Lee S, Chen D, Kim U,Kim Y,Kim S and Kim E: Effects of different calcium silicate cements on the inflammatory response and odontogenic differentiation of lipopolysaccharide-stimulated human dental pulp stem cells. Materials (Basel) 12: 1259, 2019.

54. Chen M, Hu DN, Pan Z, Lu CW, Xue CY and Aass I: Curcumin protects against hyperosmoticity-induced IL-1beta elevation in human corneal epithelial cell via MAPK pathways. Exp Eye Res 90: 437-443, 2010.

55. Tang JJ, Shen ZS, Qin W and Lin Z: A comparison of the sealing abilities between Biodentine and MTA as root-end filling materials and their effects on bone healing in dogs after periradicular surgery. J Appl Oral Sci 27: e20180693, 2019.

56. Zhang W and Peng B: Tissue reactions after subcutaneous and intraosseous implantation of iRoot SP, MTA and AH Plus. Dent Mater J 34: 774-780, 2015.

57. Masuda-Murakami Y, Kobayashi M, Wang X, Yamada Y, Kimura Y, Hossain M and Matsumoto K: Effects of mineral trioxide aggregate on the differentiation of rat dental pulp cells. Acta Histochem 112: 452-458, 2010.

58. Agrafioti A, Taraslia V, Chrepa V, Lymperi S, Panopoulos P, Anastasiadou E and Kontakiotis EG: Interaction of dental pulp stem cells with Biodentine and MTA after exposure to different environments. J Appl Oral Sci 24: 481-486, 2016.

59. Utneja S, Nawal RR, Talwar S and Verma M: Current perspectives of bio-ceramic technology in endodontics: Calcium enriched mixture cement-review of its composition, properties and applications. Restor Dent Endod 40: 1-13, 2015.

60. Bin CV, Valera MC, Camargo SE, Rabelo SB, Silva GO, Balducci I and Camargo $\mathrm{CH}$ : Cytotoxicity and genotoxicity of root canal sealers based on mineral trioxide aggregate. J Endod 38: 495-500, 2012.

61. Liu X, Zhao M, Lu J, Ma J, Wei J and Wei S: Cell responses to two kinds of nanohydroxyapatite with different sizes and crystallinities. Int J Nanomedicine 7: 1239-1250, 2012.

62. Hanafy AK, Shinaishin SF, Eldeen GN and Aly RM: Nano Hydroxyapatite \& mineral trioxide aggregate efficiently promote odontogenic differentiation of dental pulp stem cells. Open Access Maced J Med Sci 6: 1727-1731, 2018.

63. Paranjpe A, Zhang H and Johnson JD: Effects of mineral trioxide aggregate on human dental pulp cells after pulp-capping procedures. J Endod 36: 1042-1047, 2010.

64. Seo MS, Hwang KG, Lee J, Kim H and Baek SH: The effect of mineral trioxide aggregate on odontogenic differentiation in dental pulp stem cells. J Endod 39: 242-248, 2013.

65. Okamoto M, Ali M, Komichi S, Watanabe M, Huang H, Ito Y, Miura J, Hirose Y, Mizuhira M, Takahashi Y, et al: Surface pre-reacted glass filler contributes to tertiary dentin formation through a mechanism different than that of hydraulic calcium-silicate cement. J Clin Med 8: 1440, 2019. 
66. Asgary S, Nazarian H, Khojasteh A and Shokouhinejad N: Gene expression and cytokine release during odontogenic differentiation of human dental pulp stem cells induced by 2 endodontic biomaterials. J Endod 40: 387-392, 2014.

67. Paranjpe A, Cacalano NA, Hume WR and Jewett A: $\mathrm{N}$-acetylcysteine protects dental pulp stromal cells from HEMA-induced apoptosis by inducing differentiation of the cells. Free Radic Biol Med 43: 1394-1408, 2007.

68. Caicedo R, Abbott PV, Alongi DJ and Alarcon MY: Clinical, radiographic and histological analysis of the effects of mineral trioxide aggregate used in direct pulp capping and pulpotomies of primary teeth. Aust Dent J 51: 297-305, 2006.

69. Maroto M, Barberia E, Planells P and García Godoy F: Dentin bridge formation after mineral trioxide aggregate (MTA) pulpotomies in primary teeth. Am J Dent 18: 151-154, 2005.

70. Javid B, Panahandeh N, Torabzadeh H, Nazarian H, Parhizkar A and Asgary S: Bioactivity of endodontic biomaterials on dental pulp stem cells through dentin. Restor Dent Endod 45: e3, 2019.

71. Kulan P, Karabiyik O, Kose GT and Kargul B: Biocompatibility of accelerated mineral trioxide aggregate on stem cells derived from human dental pulp. J Endod 42: 276-279, 2016

72. Kim JH, Kim SY, Woo SM, Jeong HN, Jung JY, Kim SM and Lim HS: Combination of mineral trioxide aggregate and propolis promotes odontoblastic differentiation of human dental pulp stem cells through ERK signaling pathway. Food Sci Biotechnol 28: 1801-1809, 2019.

73. Olcay K, Tasli PN, Guven EP, Ulker G, Ogut EE, Ciftcioglu E, Kiratli B and Sahin F: Effect of a novel bioceramic root canal sealer on the angiogenesis-enhancing potential of assorted human odontogenic stem cells compared with principal tricalcium silicate-based cements. J Appl Oral Sci 28: e20190215, 2020.

74. Tomas-Catala CJ, Collado-Gonzalez M, Garcia-Bernal D Onate-Sanchez RE, Forner L, Llena C, Lozano A, Moraleda JM and Rodriguez-Lozano FJ: Biocompatibility of New Pulp-capping Materials NeoMTA Plus, MTA Repair HP, and biodentine on human dental pulp stem cells. J Endod 44: 126-132, 2018.

75. Luo Z, Li D, Kohli MR, Yu Q, Kim S and He WX: Effect of Biodentine $^{\mathrm{TM}}$ on the proliferation, migration and adhesion of human dental pulp stem cells. J Dent 42: 490-497, 2014

76. Luo Z, Kohli MR, Yu Q, Kim S, Qu T and He WX: Biodentine induces human dental pulp stem cell differentiation through mitogen-activated protein kinase and calcium-/calmodulin-dependent protein kinase II pathways. J Endod 40: 937-942, 2014.

77. Bortoluzzi EA, Niu LN, Palani CD, El-Awady AR, Hammond BD, Pei DD, Tian FC, Cutler CW, Pashley DH and Tay FR: Cytotoxicity and osteogenic potential of silicate calcium cements as potential protective materials for pulpal revascularization. Dent Mater 31: 1510-1522, 2015.

78. Jeanneau C, Laurent P, Rombouts C, Giraud T and About I: Light-cured tricalcium silicate toxicity to the dental pulp. J Endod 43: 2074-2080, 2017.

79. Weekate K, Chuenjitkuntaworn B, Chuveera P, Vaseenon S, Chompu-Inwai $\mathrm{P}$, Ittichaicharoen $\mathrm{J}$, Chattipakorn $\mathrm{S}$ and Srisuwan T: Alterations of mitochondrial dynamics, inflammation and mineralization potential of lipopolysaccharide-induced human dental pulp cells after exposure to $\mathrm{N}$-acetyl cysteine, Biodentine or ProRoot MTA. Int Endod J: Jan 27, 2021 (Epub ahead of print)

80. Loison-Robert LS, Tassin M, Bonte E, Berbar T, Isaac J, Berdal A Simon S and Fournier BPJ: In vitro effects of two silicate-based materials, Biodentine and BioRoot RCS, on dental pulp stem cells in models of reactionary and reparative dentinogenesis. PLoS One 13: e190014, 2018.

81. Kuru S, Sepet E, Irez T, Aktas E, Yazir Y, Duruksu G, Osmanoglu Akyol E and Erguven M: Effects of different pulp-capping materials on cell death signaling pathways of lipoteichoic acid-stimulated human dental pulp stem cells. Odontology 109: 547-559, 2021.

82. Petta TM, Pedroni ACF, Saavedra DF, Faial KDCF, Marques MM and Couto RSD: The effect of three different pulp capping cements on mineralization of dental pulp stem cells. Dent Mater J 39: 222-228, 2020.

83. Tsujimoto M, Ookubo A, Wada Y, Matsunaga T, Tsujimoto Y and Hayashi Y: Surface changes of mineral trioxide aggregate after the application of bleaching agents: Electron microscopy and an energy-dispersive X-ray microanalysis. J Endod 37: 231-234, 2011.

84. Namazikhah MS, Nekoofar MH, Sheykhrezae MS, Salariyeh S, Hayes SJ, Bryant ST, Mohammadi MM and Dummer PM: The effect of $\mathrm{pH}$ on surface hardness and microstructure of mineral trioxide aggregate. Int Endod J 41: 108-116, 2008.
85. Shie MY, Huang TH, Kao CT, Huang CH and Ding SJ: The effect of a physiologic solution $\mathrm{pH}$ on properties of white mineral trioxide aggregate. J Endod 35: 98-101, 2009.

86. Widbiller M, Lindner SR, Buchalla W, Eidt A, Hiller KA, Schmalz G and Galler KM: Three-dimensional culture of dental pulp stem cells in direct contact to tricalcium silicate cements. Clin Oral Investig 20: 237-246, 2016.

87. Chen S, Gluhak-Heinrich J, Wang YH, Wu YM, Chuang HH, Chen L, Yuan GH, Dong J, Gay I and MacDougall M: Runx2, osx, and dspp in tooth development. J Dent Res 88: 904-909, 2009.

88. Li S, Kong H, Yao N, Yu Q, Wang P, Lin Y, Wang J, Kuang R, Zhao $\mathrm{X}, \mathrm{Xu} \mathrm{J}$, et al: The role of runt-related transcription factor 2 (Runx2) in the late stage of odontoblast differentiation and dentin formation. Biochem Biophys Res Commun 410: 698-704, 2011.

89. Lambrichts I, Driesen RB, Dillen Y, Gervois P, Ratajczak J, Vangansewinkel T, Wolfs E, Bronckaers A and Hilkens P: Dental pulp stem cells: Their potential in reinnervation and angiogenesis by using Scaffolds. J Endod 43: S12-S16, 2017.

90. Brown LF, Detmar M, Claffey K, Nagy JA, Feng D, Dvorak AM and Dvorak HF: Vascular permeability factor/vascular endothelial growth factor: A multifunctional angiogenic cytokine. EXS 79: 233-269, 1997

91. Folkman J and Shing Y: Angiogenesis. J Biol Chem 267: 10931-10934, 1992.

92. Bai F, Wang Z, Lu J, Liu J, Chen G, Lv R, Wang J, Lin K, Zhang $\mathrm{J}$ and Huang $\mathrm{X}$ : The correlation between the internal structure and vascularization of controllable porous bioceramic materials in vivo: A quantitative study. Tissue Eng Part A 16: 3791-3803, 2010.

93. Wang J, Fangteng JZ and Liu H: Effect of iRoot BP Plus on biological behavior of deciduous tooth pulp stem cells and human pulp stem cells. Shanghai Kou Qiang Yi Xue 28: 251-258, 2019 (In Chinese).

94.Zhu L, Yang J, Zhang J, Lei D, Xiao L, Cheng X, Lin Y and Peng B: In vitro and in vivo evaluation of a nanoparticulate bioceramic paste for dental pulp repair. Acta Biomater 10: 5156-5168, 2014.

95. Kuo JC: Mechanotransduction at focal adhesions: Integrating cytoskeletal mechanics in migrating cells. J Cell Mol Med 17: 704-712, 2013

96. Plotnikov SV and Waterman CM: Guiding cell migration by tugging. Curr Opin Cell Biol 25: 619-626, 2013.

97. Sun Y, Luo T, Shen Y, Haapasalo M, Zou L and Liu J: Effect of iRoot fast set root repair material on the proliferation, migration and differentiation of human dental pulp stem cells in vitro. PLoS One 12: e0186848, 2017.

98. Sun Y, Liu J, Luo T, Shen Y and Zou L: Effects of two fast-setting pulp-capping materials on cell viability and osteogenic differentiation in human dental pulp stem cells: An in vitro study. Arch Oral Biol 100: 100-105, 2019.

99. Collado-Gonzalez M, Lopez-Garcia S, Garcia-Bernal D, Onate-Sanchez RE, Tomas-Catala CJ, Moraleda JM, Lozano A, Forner L and Rodriguez-Lozano FJ: Biological effects of acid-eroded MTA Repair HP and ProRoot MTA on human periodontal ligament stem cells. Clin Oral Investig 23: 3915-3924, 2019.

100. Collado-Gonzalez M, Garcia-Bernal D, Onate-Sanchez RE, Ortolani-Seltenerich PS, Lozano A, Forner L, Llena C and Rodriguez-Lozano FJ: Biocompatibility of three new calcium silicate-based endodontic sealers on human periodontal ligament stem cells. Int Endod J 50: 875-884, 2017.

101. Collado-Gonzalez M, Tomas-Catala CJ, Onate-Sanchez RE, Moraleda JM and Rodriguez-Lozano FJ: Cytotoxicity of GuttaFlow Bioseal, GuttaFlow2, MTA Fillapex, and AH Plus on human periodontal ligament stem cells. J Endod 43: 816-822, 2017.

102. Rodriguez-Lozano FJ, Garcia-Bernal D, Onate-Sanchez RE, Ortolani-Seltenerich PS, Forner L and Moraleda JM: Evaluation of cytocompatibility of calcium silicate-based endodontic sealers and their effects on the biological responses of mesenchymal dental stem cells. Int Endod J 50: 67-76, 2017.

103. Wang Y, Zhou Y, Jin L, Pang X, Lu Y, Wang Z, Yu Y and Yu J: Mineral trioxide aggregate enhances the osteogenic capacity of periodontal ligament stem cells via NF- $\kappa \mathrm{B}$ and MAPK signaling pathways. J Cell Physiol 233: 2386-2397, 2018.

104. Abuarqoub D, Aslam N, Jafar H, Abu Harfil Z and Awidi A: Biocompatibility of Biodentine ${ }^{\mathrm{TM}(\mathrm{R})}$ with periodontal ligament stem cells: In vitro study. Dent J (Basel) 8: 17, 2020. 
105. Hakki SS, Bozkurt SB, Ozcopur B, Purali N and Belli S: Periodontal ligament fibroblast response to root perforations restored with different materials: A laboratory study. Int Endod J 45: 240-248, 2012.

106. Lee MN, Hwang HS, Oh SH, Roshanzadeh A, Kim JW, Song JH, Kim ES and Koh JT: Elevated extracellular calcium ions promote proliferation and migration of mesenchymal stem cells via increasing osteopontin expression. Exp Mol Med 50: 1-16, 2018.

107. D'Anto V, Di Caprio MP, Ametrano G, Simeone M, Rengo S and Spagnuolo G: Effect of mineral trioxide aggregate on mesenchymal stem cells. J Endod 36: 1839-1843, 2010.

108. Eid AA, Hussein KA, Niu LN, Li GH, Watanabe I, Al-Shabrawey M, Pashley DH and Tay FR: Effects of tricalcium silicate cements on osteogenic differentiation of human bone marrow-derived mesenchymal stem cells in vitro. Acta Biomater 10: 3327-3334, 2014

109. Edrees HY, Abu Zeid ST, Atta HM and AlQriqri MA: Induction of osteogenic differentiation of mesenchymal stem cells by bioceramic root repair material. Materials (Basel) 12: 2311, 2019.

110. Wang Y, Li J, Song W and Yu J: Mineral trioxide aggregate upregulates odonto/osteogenic capacity of bone marrow stromal cells from craniofacial bones via JNK and ERK MAPK signalling pathways. Cell Prolif 47: 241-248, 2014.

111. Vidovic Zdrilic I, de Azevedo Queiroz IO, Matthews BG, Gomes-Filho JE, Mina M and Kalajzic I: Mineral trioxide aggregate improves healing response of periodontal tissue to injury in mice. J Periodontal Res 52: 1058-1067, 2017.

112. Moon HJ, Lee JH, Kim JH, Knowles JC, Cho YB, Shin DH, Lee $\mathrm{HH}$ and Kim HW: Reformulated mineral trioxide aggregate components and the assessments for use as future dental regenerative cements. J Tissue Eng 9: 2041731418807396, 2018

113. Gandolfi MG, Ciapetti G, Perut F, Taddei P, Modena E, Rossi PL and Prati C: Biomimetic calcium-silicate cements aged in simulated body solutions. Osteoblast response and analyses of apatite coating. J Appl Biomater Biomech 7: 160-170, 2009.

114. Lu J, Li Z, Wu X, Chen Y, Yan M, Ge X and Yu J: iRoot BP Plus promotes osteo/odontogenic differentiation of bone marrow mesenchymal stem cells via MAPK pathways and autophagy. Stem Cell Res Ther 10: 222, 2019.

115. De-Deus G, Canabarro A, Alves G, Linhares A, Senne MI and Granjeiro JM: Optimal cytocompatibility of a bioceramic nanoparticulate cement in primary human mesenchymal cells J Endod 35: 1387-1390, 2009.

116. Fathy SM, Abd El-Aziz AM and Labah DA: Cellular interaction and antibacterial efficacy of two hydraulic calcium silicate-based cements: Cell-dependent model. J Conserv Dent 22: 17-22, 2019.

117. Margunato S, Tasli PN, Aydin S, Karapınar Kazandağ M and Sahin F: In Vitro evaluation of ProRoot MTA, biodentine, and MM-MTA on human alveolar bone marrow stem cells in terms of biocompatibility and mineralization. J Endod 41: 1646-1652, 2015

118. Sultana N, Singh M, Nawal RR, Chaudhry S, Yadav S, Mohanty S and Talwar S: Evaluation of biocompatibility and osteogenic potential of tricalcium silicate-based cements using human bone marrow-derived mesenchymal stem cells.JEndod 44:446-451,2018

119. Costa F, Sousa Gomes P and Fernandes MH: Osteogenic and angiogenic response to calcium silicate-based endodontic sealers. J Endod 42: 113-119, 2016.

120. Ali MRW, Mustafa M, Bardsen A and Bletsa A: Tricalcium silicate cements: Osteogenic and angiogenic responses of human bone marrow stem cells. Eur J Oral Sci 127: 261-268, 2019.

121. Grech L, Mallia B and Camilleri J: Characterization of set Intermediate Restorative Material, Biodentine, Bioaggregate and a prototype calcium silicate cement for use as root-end filling materials. Int Endod J 46: 632-641, 2013.

122. Kang JY, Lee BN, Son HJ, Koh JT, Kang SS, Son HH, Chang HS Hwang IN, Hwang YC and Oh WM: Biocompatibility of mineral trioxide aggregate mixed with hydration accelerators. J Endod 39: 497-500, 2013.

123. Silva EJ, Rosa TP, Herrera DR, Jacinto RC, Gomes BP and Zaia AA: Evaluation of cytotoxicity and physicochemical properties of calcium silicate-based endodontic sealer MTA Fillapex. J Endod 39: 274-277, 2013.

124. Estrela C, Alencar AH, Kitten GT, Vencio EF and Gava E: Mesenchymal stem cells in the dental tissues: Perspectives for tissue regeneration. Braz Dent J 22: 91-98, 2011

125. Collado-Gonzalez M, Garcia-Bernal D, Onate-Sanchez RE, Ortolani-Seltenerich PS, Alvarez-Muro T, Lozano A, Forner L, Llena C, Moraleda JM and Rodriguez-Lozano FJ: Cytotoxicity and bioactivity of various pulpotomy materials on stem cells from human exfoliated primary teeth. Int Endod J 50 Suppl 2: e19-e30, 2017.
126. Araujo LB, Cosme-Silva L, Fernandes AP, Oliveira TM, Cavalcanti BDN, Gomes Filho JE and Sakai VT: Effects of mineral trioxide aggregate, BiodentineTM and calcium hydroxide on viability, proliferation, migration and differentiation of stem cells from human exfoliated deciduous teeth. J Appl Oral Sci 26: e20160629, 2018

127. Dahake PT, Panpaliya NP, Kale YJ, Dadpe MV, Kendre SB and Bogar C: Response of stem cells from human exfoliated deciduous teeth (SHED) to three bioinductive materials-An in vitro experimental study. Saudi Dent J 32: 43-51, 2020.

128. Hasweh N, Awidi A, Rajab L, Hiyasat A, Jafar H, Islam N, Hasan M and Abuarqoub D: Characterization of the biological effect of Biodentine(TM) on primary dental pulp stem cells. Indian J Dent Res 29: 787-793, 2018.

129. Athanasiadou E, Paschalidou M, Theocharidou A, Kontoudakis N, Arapostathis K and Bakopoulou A: Biological interactions of a calcium silicate based cement (Biodentine) with stem cells from human exfoliated deciduous teeth. Dent Mater 34: 1797-1813, 2018.

130. Tsai CL, Ke MC, Chen YH, Kuo HK, Yu HJ, Chen CT, Tseng YC, Chuang PC and Wu PC: Mineral trioxide aggregate affects cell viability and induces apoptosis of stem cells from human exfoliated deciduous teeth. BMC Pharmacol Toxicol 19: 21, 2018.

131. Saidon J, He J, Zhu Q, Safavi K and Spangberg LS: Cell and tissue reactions to mineral trioxide aggregate and Portland cement. Oral Surg Oral Med Oral Pathol Oral Radiol Endod 95: 483-489, 2003.

132. Torabinejad M, Hong CU, McDonald F and Pitt Ford TR: Physical and chemical properties of a new root-end filling material. J Endod 21: 349-353, 1995.

133. Wongwatanasanti N, Jantarat J, Sritanaudomchai $H$ and Hargreaves KM: Effect of bioceramic materials on proliferation and odontoblast differentiation of human stem cells from the apical papilla. J Endod 44: 1270-1275, 2018.

134. Peters OA, Galicia J, Arias A, Tolar M, Ng E and Shin SJ: Effects of two calcium silicate cements on cell viability, angiogenic growth factor release and related gene expression in stem cells from the apical papilla. Int Endod J 49: 1132-1140, 2016.

135. Schneider R, Holland GR, Chiego D Jr, Hu JC, Nör JE and Botero TM: White mineral trioxide aggregate induces migration and proliferation of stem cells from the apical papilla. J Endod 40: 931-936, 2014

136. Saberi EA, Karkehabadi H and Mollashahi NF: Cytotoxicity of various endodontic materials on stem cells of human apical papilla. Iran Endod J 11: 17-22, 2016.

137. Miller AA, Takimoto K, Wealleans J and Diogenes A: Effect of 3 bioceramic materials on stem cells of the apical papilla proliferation and differentiation using a dentin disk model. J Endod 44: 599-603, 2018.

138. Du J, Lu Y, Song M, Yang L, Liu J, Chen X, Ma Y and Wang Y: Effects of ERK/p38 MAPKs signaling pathways on MTA-mediated osteo/odontogenic differentiation of stem cells from apical papilla: A vitro study. BMC Oral Health 20: 50, 2020.

139. Saberi E, Farhad-Mollashahi N, Sargolzaei Aval F and Saberi M: Proliferation, odontogenic/osteogenic differentiation, and cytokine production by human stem cells of the apical papilla induced by biomaterials: A comparative study. Clin Cosmet Investig Dent 11: 181-193, 2019.

140. Hajizadeh N, Madani ZS, Zabihi E, Golpour M, Zahedpasha A and Mohammadnia M: Effect of MTA and CEM on mineralization-associated gene expression in stem cells derived from apical papilla. Iran Endod J 13: 94-101, 2018.

141. Chang J, Liu F, Lee M, Wu B, Ting K, Zara JN, Soo C Al Hezaimi K, Zou W, Chen X, et al: NF- $\kappa$ B inhibits osteogenic differentiation of mesenchymal stem cells by promoting $\beta$-catenin degradation. Proc Natl Acad Sci USA 110: 9469-9474, 2013.

142. Yan M, Wu J, Yu Y, Wang Y, Xie L, Zhang G, Yu J and Zhang C: Mineral trioxide aggregate promotes the odonto/osteogenic differentiation and dentinogenesis of stem cells from apical papilla via nuclear factor kappa B signaling pathway. J Endod 40: 640-647, 2014

143. Li H and Chang J: Bioactive silicate materials stimulate angiogenesis in fibroblast and endothelial cell co-culture system through paracrine effect. Acta Biomater 9: 6981-6991, 2013.

144. Day RM: Bioactive glass stimulates the secretion of angiogenic growth factors and angiogenesis in vitro. Tissue Eng 11: 768-777, 2005 . 
145. Leu A and Leach JK: Proangiogenic potential of a collagen/bioactive glass substrate. Pharm Res 25: 1222-1229, 2008.

146. Wang G, Roohani-Esfahani SI, Zhang W, Lv K, Yang G, Ding X, Zou D, Cui D, Zreiqat H and Jiang X: Effects of Sr-HT-Gahnite on osteogenesis and angiogenesis by adipose derived stem cells for critical-sized calvarial defect repair. Sci Rep 7: 41135, 2017.

147. Liu Y, Liu XM, Bi J, Yu S, Yang N, Song B and Chen X: Cell migration and osteo/odontogenesis stimulation of iRoot FS as a potential apical barrier material in apexification. Int Endod J 53 467-477, 2020.

148. Bi J, Liu Y, Liu XM, Jiang LM and Chen X: iRoot FM exerts an antibacterial effect on Porphyromonas endodontalis and improves the properties of stem cells from the apical papilla. Int Endod J 51: 1139-1148, 2018.

149. Dogan A, Yalvac ME, Sahin F, Kabanov AV, Palotas A and Rizvanov AA: Differentiation of human stem cells is promoted by amphiphilic pluronic block copolymers. Int J Nanomedicine 7: 4849-4860, 2012

150. Dogan A, Demirci S and Sahin F: In vitro differentiation of human tooth germ stem cells into endothelial- and epithelial-like cells. Cell Biol Int 39: 94-103, 2015.

151. Guven EP, Yalvac ME, Sahin F, Yazici MM, Rizvanov AA and Bayirli G: Effect of dental materials calcium hydroxidecontaining cement, mineral trioxide aggregate, and ename matrix derivative on proliferation and differentiation of human tooth germ stem cells. J Endod 37: 650-656, 2011

152. Guven EP, Yalvac ME, Kayahan MB, Sunay H, Sahin F and Bayirli G: Human tooth germ stem cell response to calcium-silicate based endodontic cements. J Appl Oral Sci 21: 351-357, 2013

153. Güven EP, Taşlı PN, Yalvac ME, Sofiev N, Kayahan MB and Sahin F: In vitro comparison of induction capacity and biomineralization ability of mineral trioxide aggregate and a bioceramic root canal sealer. Int Endod J 46: 1173-1182, 2013.

154. Jiang N, Guo W, Chen M, Zheng Y, Zhou J, Kim SG, Embree MC Songhee Song K, Marao HF and Mao JJ: Periodontal ligament and alveolar bone in health and adaptation: Tooth movement Front Oral Biol 18: 1-8, 2016.

155. Zhou Y, Wu C and Xiao Y: Silicate-based bioceramics for periodontal regeneration. J Mater Chem B 2: 3907-3910, 2014.

156. Proksch S, BrossartJ, Vach K, Hellwig E, Altenburger MJ and Karygianni L: Evaluation of the bioactivity of fluoride-enriched mineral trioxide aggregate on osteoblasts. Int Endod J 51: 912-923, 2018

157. Nakayama A, Ogiso B, Tanabe N, Takeichi O, Matsuzaka K and Inoue T: Behaviour of bone marrow osteoblast-like cells on mineral trioxide aggregate: Morphology and expression of type I collagen and bone-related protein mRNAs. Int Endod J 38: 203-210, 2005.

158. Castro-Raucci LM, Teixeira LN, Oliveira IR, Raucci-Neto W, Jacobovitz M, Rosa AL and de Oliveira PT: Osteogenic cell response to calcium aluminate-based cement. Int Endod J 50: 771-779, 2017.

159. Castro-Raucci LM, Oliveira IR, Teixeira LN, Rosa AL, Oliveira PT and Jacobovitz M: Effects of a novel calcium aluminate cement on the early events of the progression of osteogenic cell cultures. Braz Dent J 22: 99-104, 2011.

160. Orrenius S, Zhivotovsky B and Nicotera P: Regulation of cell death: The calcium-apoptosis link. Nat Rev Mol Cell Biol 4 $552-565,2003$.

161. Dvorak MM and Riccardi D: $\mathrm{Ca}^{2+}$ as an extracellular signal in bone. Cell Calcium 35: 249-255, 2004.

162. Oliveira IR, Andrade TL, Jacobovitz M and Pandolfelli VC: Bioactivity of calcium aluminate endodontic cement J Endod 39: 774-778, 2013

163. Pires-de-Souza FC, Moraes PC, Garcia Lda F, Aguilar FG and Watanabe E: Evaluation of $\mathrm{pH}$, calcium ion release and antimicrobial activity of a new calcium aluminate cement. Braz Oral Res 27: 324-330, 2013

164. Scelza MZ, Nascimento JC, Silva LE, Gameiro VS, DE Deus G and Alves G: Biodentine ${ }^{\mathrm{TM}}$ is cytocompatible with human primary osteoblasts. Braz Oral Res 31: e81, 2017.

165. Coelho MJ and Fernandes MH: Human bone cell cultures in biocompatibility testing. Part II: Effect of ascorbic acid, beta-glycerophosphate and dexamethasone on osteoblastic differentiation. Biomaterials 21: 1095-1102, 2000.

166. Rifaey HS, Villa M, Zhu Q, Wang YH, Safavi K and Chen IP: Comparison of the osteogenic potential of mineral trioxide aggregate and endosequence root repair material in a 3-dimensional culture system. J Endod 42: 760-765, 2016
167. Ciasca M, Aminoshariae A, Jin G, Montagnese T and Mickel A A comparison of the cytotoxicity and proinflammatory cytokine production of EndoSequence root repair material and ProRoot mineral trioxide aggregate in human osteoblast cell culture using reverse-transcriptase polymerase chain reaction. J Endod 38: 486-489, 2012

168. Tani-Ishii N, Hamada N, Watanabe K, Tujimoto Y, Teranaka T and Umemoto $\mathrm{T}$ : Expression of bone extracellular matrix proteins on osteoblast cells in the presence of mineral trioxide. J Endod 33: 836-839, 2007.

169. Yoshimine $\mathrm{Y}$, Ono $\mathrm{M}$ and Akamine A: In vitro comparison of the biocompatibility of mineral trioxide aggregate, 4META/MMA-TBB resin, and intermediate restorative material as root-end-filling materials. J Endod 33: 1066-1069, 2007.

170. Maeda T, Suzuki A, Yuzawa S, Baba Y, Kimura Y and Kato Y: Mineral trioxide aggregate induces osteoblastogenesis via Atf6. Bone Rep 2: 36-43, 2015 .

171. Lee GW, Yoon JH, Jang JH, Chang HS, Hwang YC, Hwang IN, Oh WM and Lee BN: Effects of newly-developed retrograde filling material on osteoblastic differentiation in vitro. Dent Mater J 38: 528-533, 2019.

172. Sarkar NK, Caicedo R, Ritwik P, Moiseyeva R and Kawashima I: Physicochemical basis of the biologic properties of mineral trioxide aggregate. J Endod 31: 97-100, 2005.

173. Estrela C, Sydney GB, Pesce HF and Felippe Júnior O: Dentinal diffusion of hydroxyl ions of various calcium hydroxide pastes. Braz Dent J 6: 5-9, 1995.

174. Ko H, Yang W, Park K and Kim M: Cytotoxicity of mineral trioxide aggregate (MTA) and bone morphogenetic protein 2 (BMP-2) and response of rat pulp to MTA and BMP-2. Oral Surg Oral Med Oral Pathol Oral Radiol Endod 109: e103-e108, 2010.

175. Wozney JM: The bone morphogenetic protein family: Multifunctional cellular regulators in the embryo and adult. Eur J Oral Sci 106 Suppl 1: S160-S166, 1998.

176. Zhu Q, Haglund R, Safavi KE and Spangberg LS: Adhesion of human osteoblasts on root-end filling materials. J Endod 26: 404-406, 2000.

177. Pelliccioni GA, Ciapetti G, Cenni E, Granchi D, Nanni M, Pagani S and Giunti A: Evaluation of osteoblast-like cell response to Proroot MTA (mineral trioxide aggregate) cement. J Mater Sci Mater Med 15: 167-173, 2004.

178. Tanomaru-Filho M, Andrade AS, Rodrigues EM, Viola KS, Faria G, Camilleri J and Guerreiro-Tanomaru JM: Biocompatibility and mineralized nodule formation of Neo MTA Plus and an experimental tricalcium silicate cement containing tantalum oxide. Int Endod J 50 (Suppl 2): e31-e39, 2017.

179. Modareszadeh MR, Di Fiore PM, Tipton DA and Salamat N: Cytotoxicity and alkaline phosphatase activity evaluation of endosequence root repair material. J Endod 38: 1101-1105, 2012.

180. Yuan Z, Peng B, Jiang H, Bian Z and Yan P: Effect of bioaggregate on mineral-associated gene expression in osteoblast cells. J Endod 36: 1145-1148, 2010

181. Jung S, Mielert J, Kleinheinz J and Dammaschke T: Human oral cells' response to different endodontic restorative materials: An in vitro study. Head Face Med 10: 55, 2014.

182. Attik GN, Villat C, Hallay F, Pradelle-Plasse N, Bonnet H, Moreau K, Colon P and Grosgogeat B: In vitro biocompatibility of a dentine substitute cement on human MG63 osteoblasts cells: Biodentine versus MTA((®)). Int Endod J 47: 1133-1141, 2014.

183. Kim HS, Kim S, Ko H, Song M and Kim M: Effects of the cathepsin $\mathrm{K}$ inhibitor with mineral trioxide aggregate cements on osteoclastic activity. Restor Dent Endod 44: e17, 2019.

184. Gomes-Cornelio AL, Rodrigues EM, Salles LP, Mestieri LB, Faria G, Guerreiro-Tanomaru JM and Tanomaru-Filho M: Bioactivity of MTA Plus, Biodentine and an experimental calcium silicate-based cement on human osteoblast-like cells. Int Endod J 50: 39-47, 2017.

185. De-Deus G, Canabarro A, Alves GG, Marins JR, Linhares AB and Granjeiro JM: Cytocompatibility of the ready-to-use bioceramic putty repair cement iRoot BP Plus with primary human osteoblasts. Int Endod J 45: 508-513, 2012.

186. Tian J, Zhang Y, Lai Z, Li M, Huang Y, Jiang H and Wei X: Ion release, microstructural, and biological properties of iRoot BP Plus and ProRoot MTA exposed to an acidic environment. J Endod 43: 163-168, 2017.

187. Lv F, Zhu L, Zhang J, Yu J, Cheng X and Peng B: Evaluation of the in vitro biocompatibility of a new fast-setting ready-to-use root filling and repair material. Int Endod J 50: 540-548, 2017. 
188. Jiang Y, Zheng Q, Zhou X, Gao Y and Huang D: A comparative study on root canal repair materials: A cytocompatibility assessment in L929 and MG63 cells. ScientificWorldJournal 2014: 463826, 2014

189. Levine BR, Sporer S, Poggie RA, Della Valle CJ and Jacobs JJ: Experimental and clinical performance of porous tantalum in orthopedic surgery. Biomaterials 27: 4671-4681, 2006.

190.Zhang W, Li Z and Peng B: Effects of iRoot SP on mineralization-related genes expression in MG63 cells. J Endod 36: 1978-1982, 2010.

191. Zhang J, Zhu L and Peng B: Effect of BioAggregate on osteoclast differentiation and inflammatory bone resorption in vivo. Int Endod J 48: 1077-1085, 2015.

192. Tian J, Qi W, Zhang Y, Glogauer M, Wang Y, Lai Z and Jiang H: Bioaggregate inhibits osteoclast differentiation, fusion, and bone resorption in vitro. J Endodont 41: 1500-1506, 2015.

193. Zhang J, Zhu L, Yan P and Peng B: Effect of BioAggregate on receptor activator of nuclear factor-kappa $B$ ligand-induced osteoclastogenesis from murine macrophage cell line in vitro. J Endod 41: 1265-1271, 2015.

194. Cheng X, Zhu L, Zhang J, Yu J, Liu S, Lv F, Lin Y, Liu G and Peng B: Anti-osteoclastogenesis of mineral trioxide aggregate through inhibition of the autophagic pathway. J Endodont 43 : 766-773, 2017

195. Hashiguchi D, Fukushima H, Nakamura M, Morikawa K, Yasuda H, Udagawa N, Maki K and Jimi E: Mineral trioxide aggregate solution inhibits osteoclast differentiation through the maintenance of osteoprotegerin expression in osteoblasts. J Biomed Mater Res A 96: 358-364, 2011.

196. Hashiguchi D, Fukushima H, Yasuda H, Masuda W, Tomikawa M, Morikawa K, Maki K and Jimi E: Mineral trioxide aggregate inhibits osteoclastic bone resorption. J Dent Res 90: 912-917, 2011.

197. Kim M, Kim S, Ko H and Song M: Effect of ProRoot MTA ${ }^{\circledR}$ and Biodentine ${ }^{\circledR}$ on osteoclastic differentiation and activity of mouse bone marrow macrophages. J Appl Oral Sci 27: e20180150, 2019.

198. Choi SC, Kwon YD, Kim KC and Kim GT: The effects of topical application of bisphosphonates on replanted rat molars. Dent Traumatol 26: 476-480, 2010.

199. Komatsu K, Shimada A, Shibata T, Shimoda S, Oida S Kawasaki K and Nifuji A: Long-term effects of local pretreatment with alendronate on healing of replanted rat teeth. J Periodontal Res 43: 194-200, 2008.

200. Tu MG, Sun KT, Wang TH, He YZ, Hsia SM, Tsai BH, Shih YH and Shieh TM: Effects of mineral trioxide aggregate and bioceramics on macrophage differentiation and polarization in vitro. J Formos Med Assoc 118: 1458-1465, 2019.

201. Camilleri J: Characterization of hydration products of mineral trioxide aggregate. Int Endod J 41: 408-417, 2008.

202. Varanasi VG, Leong KK, Dominia LM, Jue SM, Loomer PM and Marshall GW: Si and Ca individually and combinatorially target enhanced MC3T3-E1 subclone 4 early osteogenic marker expression. J Oral Implantol 38: 325-336, 2012.

203. Xia L, Yin Z, Mao L, Wang X, Liu J, Jiang X, Zhang Z, Lin K, Chang J and Fang B: Akermanite bioceramics promote osteogenesis, angiogenesis and suppress osteoclastogenesis for osteoporotic bone regeneration. Sci Rep 6: 22005, 2016.

204.Wu C, Chen Z, Yi D, Chang J and Xiao Y: Multidirectional effects of $\mathrm{Sr}-, \mathrm{Mg}-$, and $\mathrm{Si}$-containing bioceramic coatings with high bonding strength on inflammation, osteoclastogenesis, and osteogenesis. ACS Appl Mater Interfaces 6: 4264-4276, 2014.

205.Hung CJ, Kao CT, Chen YJ, Shie MY and Huang TH: Antiosteoclastogenic activity of silicate-based materials antagonizing receptor activator for nuclear factor kappaB ligand-induced osteoclast differentiation of murine marcophages. J Endod 39: 1557-1561, 2013.

206. Sun T, Wang M, Shao Y, Wang L and Zhu Y: The effect and osteoblast signaling response of trace silicon doping hydroxyapatite. Biol Trace Elem Res 181: 82-94, 2018

207. Wang S, Wang X, Draenert FG, Albert O, Schroder HC Mailander V, Mitov G and Muller WE: Bioactive and biodegradable silica biomaterial for bone regeneration. Bone 67: 292-304, 2014.

208.Zhai W, Lu H, Wu C, Chen L, Lin X, Naoki K, Chen G and Chang J: Stimulatory effects of the ionic products from $\mathrm{Ca}-\mathrm{Mg}-\mathrm{Si}$ bioceramics on both osteogenesis and angiogenesis in vitro. Acta Biomater 9: 8004-8014, 2013.
209. Gough JE, Notingher I and Hench LL: Osteoblast attachment and mineralized nodule formation on rough and smooth 45S5 bioactive glass monoliths. J Biomed Mater Res A 68: 640-650, 2004

210. Gough JE, Clupper DC and Hench LL: Osteoblast responses to tape-cast and sintered bioactive glass ceramics. J Biomed Mater Res A 69: 621-628, 2004.

211. Ibrahim S, Sabudin S, Sahid S, Marzuke MA, Hussin ZH, Kader Bashah NS and Jamuna-Thevi K: Bioactivity studies and adhesion of human osteoblast (hFOB) on silicon-biphasic calcium phosphate material. Saudi J Biol Sci 23: S56-S63, 2016

212. Caudrillier A, Hurtel-Lemaire AS, Wattel A, Cournarie F, Godin C,Petit L,Petit JP, Terwilliger E, Kamel S, Brown EM, et al: Strontium ranelate decreases receptor activator of nuclear factor- $\kappa \mathrm{B}$ ligand-induced osteoclastic differentiation in vitro: Involvement of the calcium-sensing receptor. Mol Pharmacol 78: 569-576, 2010.

213. Mladenovic Z, Johansson A, Willman B, Shahabi K, Bjorn E and Ransjo M: Soluble silica inhibits osteoclast formation and bone resorption in vitro. Acta Biomater 10: 406-418, 2014.

214. Okabe T, Sakamoto M, Takeuchi H and Matsushima K: Effects of $\mathrm{pH}$ on mineralization ability of human dental pulp cells. J Endod 32: 198-201, 2006.

215. Stuart CH, Schwartz SA, Beeson TJ and Owatz CB: Enterococcus faecalis: Its role in root canal treatment failure and current concepts in retreatment. J Endod 32: 93-98, 2006.

216. Gao J, Wang M, Shi C, Wang L, Wang D and Zhu Y: Synthesis of trace element $\mathrm{Si}$ and $\mathrm{Sr}$ codoping hydroxyapatite with non-cytotoxicity and enhanced cell proliferation and differentiation. Biol Trace Elem Res 174: 208-217, 2016.

217. Lin LM and Rosenberg PA: Repair and regeneration in endodontics. Int Endod J 44: 889-906, 2011.

218. Koulaouzidou EA, Economides N, Beltes P, Geromichalos G and Papazisis K: In vitro evaluation of the cytotoxicity of ProRoot MTA and MTA Angelus. J Oral Sci 50: 397-402, 2008

219. Peng W, Liu W, Zhai W, Jiang L, Li L, Chang J and Zhu Y: Effect of tricalcium silicate on the proliferation and odontogenic differentiation of human dental pulp cells. J Endod 37: 1240-1246, 2011.

220.Kim DH, Jang JH, Lee BN, Chang HS, Hwang IN, Oh WM, Kim SH, Min KS, Koh JT and Hwang YC: Anti-inflammatory and mineralization effects of ProRoot MTA and endocem MTA in studies of human and rat dental pulps in vitro and in vivo. J Endod 44: 1534-1541, 2018.

221. Liu CH, Huang TH, Hung CJ, Lai WY, Kao CT and Shie MY: The synergistic effects of fibroblast growth factor- 2 and mineral trioxide aggregate on an osteogenic accelerator in vitro. Int Endod J 47: 843-853, 2014.

222. Chung CJ, Kim E, Song M, Park JW and Shin SJ: Effects of two fast-setting calcium-silicate cements on cell viability and angiogenic factor release in human pulp-derived cells. Odontology 104: 143-151, 2016.

223. Chang SW, Lee SY, Kum KY and Kim EC: Effects of ProRoot MTA, Bioaggregate, and Micromega MTA on odontoblastic differentiation in human dental pulp cells. J Endod 40: 113-118, 2014.

224.Jung JY, Woo SM, Lee BN, Koh JT, Nor JE and Hwang YC: Effect of Biodentine and Bioaggregate on odontoblastic differentiation via mitogen-activated protein kinase pathway in human dental pulp cells. Int Endod J 48: 177-184, 2015.

225.Zhu L, Yang J, Zhang J and Peng B: A comparative study of BioAggregate and ProRoot MTA on adhesion, migration, and attachment of human dental pulp cells. J Endod 40: 1118-1123, 2014.

226.Zhang S, Yang X and Fan M: BioAggregate and iRoot BP Plus optimize the proliferation and mineralization ability of human dental pulp cells. Int Endod J 46: 923-929, 2013.

227. Tomson PL, Grover LM, Lumley PJ, Sloan AJ, Smith AJ and Cooper PR: Dissolution of bio-active dentine matrix components by mineral trioxide aggregate. J Dent 35: 636-642, 2007.

228. Laurent P, Camps J and About I: Biodentine(TM) induces TGF- $\beta 1$ release from human pulp cells and early dental pulp mineralization. Int Endod J 45: 439-448, 2012.

229. Zanini M, Sautier JM, Berdal A and Simon S: Biodentine induces immortalized murine pulp cell differentiation into odontoblast-like cells and stimulates biomineralization. J Endod 38: 1220-1226, 2012.

230. Liu S, Wang S and Dong Y: Evaluation of a bioceramic as a pulp capping agent in vitro and in vivo. J Endod 41: 652-657, 2015. 
231. Zhang J, Zhu LX, Cheng X, Lin Y, Yan P and Peng B: Promotion of dental pulp cell migration and pulp repair by a bioceramic putty involving FGFR-mediated signaling pathways. J Dent Res 94: 853-862, 2015.

232. Kierat A, Laszczynska M, Kowalska E and Weyna E: Comparison of the influence of mineral trioxide aggregate and calcium hydroxide on dental pulp of permanent teeth in biological treatment and cell cultures. Ann Acad Med Stetin 56 89-96, 2010 (In Polish).

233. Zakerzadeh A, Esnaashari E and Dadfar S: In Vitro comparison of cytotoxicity and genotoxicity of three vital pulp capping materials. Iran Endod J 12: 419-425, 2017.

234. Nikfarjam F, Beyer K, Konig A, Hofmann M, Butting M, Valesky E, Kippenberger S, Kaufmann R, Heidemann D, Bernd A and Zöller NN: Influence of Biodentine(R)-A dentine substitute-on collagen type $\mathrm{i}$ synthesis in pulp fibroblasts in vitro. PLoS One 11: e167633, 2016

235. Begue-Kirn C, Smith AJ, Ruch JV, Wozney JM, Purchio A, Hartmann D and Lesot $\mathrm{H}$ : Effects of dentin proteins, transforming growth factor beta 1 (TGF beta 1) and bone morphogenetic protein 2 (BMP2) on the differentiation of odontoblast in vitro. Int J Dev Biol 36: 491-503, 1992.

236. Strong DD, Beachler AL, Wergedal JE and Linkhart TA: Insulinlike growth factor II and transforming growth factor beta regulate collagen expression in human osteoblastlike cells in vitro. J Bone Miner Res 6: 15-23, 1991.

237. Helder MN, Bronckers AL and Woltgens JH: Dissimilar expression patterns for the extracellular matrix proteins osteopontin (OPN) and collagen type I in dental tissues and alveolar bone of the neonatal rat. Matrix 13: 415-425, 1993.

238. Mathieu S, Jeanneau C, Sheibat-Othman N, Kalaji N, Fessi H and About I: Usefulness of controlled release of growth factors in investigating the early events of dentin-pulp regeneration. J Endod 39: 228-235, 2013.

239. Shimabukuro Y, Ueda M, Ozasa M, Anzai J, Takedachi M, Yanagita M, Ito M, Hashikawa T, Yamada S and Murakami S: Fibroblast growth factor-2 regulates the cell function of human dental pulp cells. J Endod 35: 1529-1535, 2009.

240. Giraud T, Jeanneau C, Bergmann M, Laurent P and About I: Tricalcium silicate capping materials modulate pulp healing and inflammatory activity in vitro. J Endod 44: 1686-1691, 2018.

241. Guo RF and Ward PA: Role of C5a in inflammatory responses. Annu Rev Immunol 23: 821-852, 2005.

242. Chmilewsky F, Jeanneau C, Dejou J and About I: Sources of dentin-pulp regeneration signals and their modulation by the local microenvironment. J Endod 40 (Suppl 4): S19-S25, 2014.

243. Giraud T, Rufas P, Chmilewsky F, Rombouts C, Dejou J, Jeanneau $C$ and About I: Complement activation by pulp capping materials plays a significant role in both inflammatory and pulp stem cells' recruitment. J Endod 43: 1104-1110, 2017.

244.Karimjee CK, Koka S, Rallis DM and Gound TG: Cellular toxicity of mineral trioxide aggregate mixed with an alternative delivery vehicle. Oral Surg Oral Med Oral Pathol Oral Radiol Endod 102: e115-e120, 2006.

245. Maeda H, Nakano T, Tomokiyo A, Fujii S, Wada N, Monnouchi S, Hori $\mathrm{K}$ and Akamine A: Mineral trioxide aggregate induces bone morphogenetic protein-2 expression and calcification in human periodontal ligament cells. J Endod 36: 647-652, 2010.

246. Kasaj A, Willershausen B, Reichert C, Rohrig B, Smeets R and Schmidt M: Ability of nanocrystalline hydroxyapatite paste to promote human periodontal ligament cell proliferation. J Oral Sci 50: 279-285, 2008.

247. Wang MC, Yeh LY, Shih WY, Li WC, Chang KW and Lin SC: Portland cement induces human periodontal ligament cells to differentiate by upregulating miR-146a. J Formos Med Assoc 117: 308-315, 2018.

248. Luo T, Liu J, Sun Y, Shen Y and Zou L: Cytocompatibility of Biodentine and iRoot FS with human periodontal ligament cells: An in vitro study. Int Endod J 51: 779-788, 2018.

249. Chang SW, Lee SY, Kang SK, Kum KY and Kim EC: In vitro biocompatibility, inflammatory response, and osteogenic potential of 4 root canal sealers: Sealapex, Sankin apatite root sealer, MTA Fillapex, and iRoot SP root canal sealer. J Endod 40 : 1642-1648, 2014.

250. Willershausen I, Wolf T, Kasaj A, Weyer V, Willershausen B and Marroquin BB: Influence of a bioceramic root end materia and mineral trioxide aggregates on fibroblasts and osteoblasts. Arch Oral Biol 58: 1232-1237, 2013.
251. Gupta SK, Saxena P, Pant VA and Pant AB: Adhesion and biologic behavior of human periodontal fibroblast cells to resin ionomer Geristore: A comparative analysis. Dent Traumatol 29: 389-393, 2013

252. Balto HA: Attachment and morphological behavior of human periodontal ligament fibroblasts to mineral trioxide aggregate: A scanning electron microscope study. J Endod 30: 25-29, 2004.

253. Bonson S, Jeansonne BG and Lallier TE: Root-end filling materials alter fibroblast differentiation. J Dent Res 83: 408-413, 2004.

254. Gorduysus M, Avcu N, Gorduysus O, Pekel A, Baran Y, Avcu F and Ural AU: Cytotoxic effects of four different endodontic materials in human periodontal ligament fibroblasts. J Endod 33 1450-1454, 2007.

255. Badr AE: Marginal adaptation and cytotoxicity of bone cement compared with amalgam and mineral trioxide aggregate as root-end filling materials. J Endod 36: 1056-1060, 2010.

256. Yoshino P, Nishiyama CK, Modena KC, Santos CF and Sipert CR: In vitro cytotoxicity of white MTA, MTA Fillapex ${ }^{(\mathrm{R})}$ and Portland cement on human periodontal ligament fibroblasts. Braz Dent J 24: 111-116, 2013.

257. Keiser K, Johnson CC and Tipton DA: Cytotoxicity of mineral trioxide aggregate using human periodontal ligament fibroblasts. J Endod 26: 288-291, 2000.

258. Al-Haj Ali SN, Al-Jundi SH and Ditto DJ: In vitro toxicity of formocresol, ferric sulphate, and grey MTA on human periodontal ligament fibroblasts. Eur Arch Paediatr Dent 16: 51-55, 2015

259. Al-Haj AS: In vitro toxicity of propolis in comparison with other primary teeth pulpotomy agents on human fibroblasts. J Investig Clin Dent 7: 308-313, 2016

260. Samyuktha V, Ravikumar P, Nagesh B, Ranganathan K, Jayaprakash T and Sayesh V: Cytotoxicity evaluation of root repair materials in human-cultured periodontal ligament fibroblasts. J Conserv Dent 17: 467-470, 2014

261. Kucukkaya S, Gorduysus MO, Zeybek ND and Muftuoglu SF: In vitro cytotoxicity of calcium silicate-based endodontic cement as root-end filling materials. Scientifica (Cairo) 2016 $9203932,2016$.

262.Jang YE, Lee BN, Koh JT, Park YJ, Joo NE, Chang HS, Hwang IN, Oh WM and Hwang YC: Cytotoxicity and physical properties of tricalcium silicate-based endodontic materials. Restor Dent Endod 39: 89-94, 2014.

263. Akbulut MB, Arpaci PU and Eldeniz AU: Effects of four novel root-end filling materials on the viability of periodontal ligament fibroblasts. Restor Dent Endod 43: e24, 2018.

264. Camilleri J, Sorrentino F and Damidot D: Investigation of the hydration and bioactivity of radiopacified tricalcium silicate cement, Biodentine and MTA Angelus. Dent Mater 29: 580-593, 2013.

265. Kim JR, Nosrat A and Fouad AF: Interfacial characteristics of Biodentine and MTA with dentine in simulated body fluid. J Dent 43: 241-247, 2015.

266. Gomes Cornélio AL, Salles LP, Campos da Paz M, Cirelli JA, Guerreiro-Tanomaru JM and Tanomaru Filho M: Cytotoxicity of Portland cement with different radiopacifying agents: A cell death study. J Endod 37: 203-210, 2011.

267. Akbulut MB, Uyar Arpaci P and Unverdi Eldeniz A: 'Effects of novel root repair materials on attachment and morphological behaviour of periodontal ligament fibroblasts: Scanning electron microscopy observation'. Microsc Res Tech 79: 1214-1221, 2016

268. Escobar-Garcia DM, Aguirre-Lopez E, Mendez-Gonzalez V and Pozos-Guillen A: Cytotoxicity and initial biocompatibility of endodontic biomaterials (MTA and Biodentine ${ }^{\mathrm{TM}}$ ) used as root-end filling materials. Biomed Res Int 2016: 7926961, 2016.

269. Futami T, Fujii N, Ohnishi H, Taguchi N, Kusakari H, Ohshima H and Maeda T: Tissue response to titanium implants in the rat maxilla: Ultrastructural and histochemical observations of the bone-titanium interface. J Periodontol 71: 287-298, 2000.

270. Kou PM and Babensee JE: Macrophage and dendritic cell phenotypic diversity in the context of biomaterials. J Biomed Mater Res A 96: 239-260, 2011

271. Gratchev A, Guillot P, Hakiy N, Politz O, Orfanos CE, Schledzewski $\mathrm{K}$ and Goerdt S: Alternatively activated macrophages differentially express fibronectin and its splice variants and the extracellular matrix protein betaIG-H3. Scand J Immunol 53: 386-392, 2001

272. Brackett MG, Lewis JB, Messer RL, Lei L, Lockwood PE and Wataha JC: Dysregulation of monocytic cytokine secretion by endodontic sealers. J Biomed Mater Res B Appl Biomater 97: $49-57,2011$. 
273. Kabashima H, Nagata K, Maeda K and Iijima T: Involvement of substance P, mast cells, TNF-alpha and ICAM-1 in the infiltration of inflammatory cells in human periapical granulomas. J Oral Pathol Med 31: 175-180, 2002.

274. Ribeiro RA, Souza-Filho MV, Souza MH, Oliveira SH, Costa $\mathrm{CH}$, Cunha FQ and Ferreira HS: Role of resident mast cells and macrophages in the neutrophil migration induced by LTB4, fMLP and C5a des arg. Int Arch Allergy Immunol 112: 27-35, 1997.

275. Gomes AC, Gomes-Filho JE and Oliveira SH: Mineral trioxide aggregate stimulates macrophages and mast cells to release neutrophil chemotactic factors: Role of IL-1beta, MIP-2 and LTB(4). Oral Surg Oral Med Oral Pathol Oral Radiol Endod 109: e135-e142, 2010.

276. Baggiolini M: Chemokines and leukocyte traffic. Nature 392: 565-568, 1998.

277. Gomes AC, Filho JE and de Oliveira SH: MTA-induced neutrophil recruitment: A mechanism dependent on IL-1beta, MIP-2, and LTB4. Oral Surg Oral Med Oral Pathol Oral Radiol Endod 106: 450-456, 2008.

278. Cavalcanti BN, Rode Sde M, Franca CM and Marques MM: Pulp capping materials exert an effect on the secretion of IL-1 $\beta$ and IL- 8 by migrating human neutrophils. Braz Oral Res 25 : $13-18,2011$.

279. Chang F, Kim JM, Choi Y and Park K: MTA promotes chemotaxis and chemokinesis of immune cells through distinct calcium-sensing receptor signaling pathways. Biomaterials 150 : $14-24,2018$.

280. Martinez FO and Gordon S: The M1 and M2 paradigm of macrophage activation: Time for reassessment. F1000Prime Rep 6: 13, 2014.

281. Murray PJ, Allen JE, Biswas SK, Fisher EA, Gilroy DW, Goerdt S, Gordon S, Hamilton JA, Ivashkiv LB, Lawrence T, et al: Macrophage activation and polarization: Nomenclature and experimental guidelines. Immunity 41: 14-20, 2014

282.Zhu X, Yuan Z, Yan P, Li Y, Jiang H and Huang S: Effect of iRoot SP and mineral trioxide aggregate (MTA) on the viability and polarization of macrophages. Arch Oral Biol 80: 27-33, 2017.

283. Braga JM, Oliveira RR, Martins RC and Ribeiro Sobrinho AP: The effects of a mineral trioxide aggregate-based sealer on the production of reactive oxygen species, nitrogen species and cytokines by two macrophage subtypes. Int Endod J 47: 909-919, 2014.
284. Rezende TM, Vieira LQ, Cardoso FP, Oliveira RR, de Oliveira Mendes ST, Jorge ML and Ribeiro Sobrinho AP: The effect of mineral trioxide aggregate on phagocytic activity and production of reactive oxygen, nitrogen species and arginase activity by M1 and M2 macrophages. Int Endod J 40: 603-611, 2007.

285. Yuan Z, Zhu X, Li Y, Yan P and Jiang H: Influence of iRoot SP and mineral trioxide aggregate on the activation and polarization of macrophages induced by lipopolysaccharide. BMC Oral Health 18: 56, 2018.

286. Yeh HW, Chiang CF, Chen PH, Su CC, Wu YC, Chou L, Huang RY, Liu SY and Shieh YS: Axl involved in mineral trioxide aggregate induces macrophage polarization. J Endod 44: 1542-1548, 2018.

287. da Silva GN, Braz MG, de Camargo EA, Salvadori DM and Ribeiro DA: Genotoxicity in primary human peripheral lymphocytes after exposure to regular and white mineral trioxide aggregate. Oral Surg Oral Med Oral Pathol Oral Radiol Endod 102: e50-e54, 2006

288. Barczak K, Palczewska-Komsa M, Nowicka A, Chlubek D and Buczkowska-Radlinska J: Analysis of the activity and expression of cyclooxygenases COX1 and COX2 in THP-1 monocytes and macrophages cultured with Biodentine ${ }^{\mathrm{TM}}$ Silicate cement. Int J Mol Sci 21: 2237, 2020.

289. Khedmat S, Dehghan S, Hadjati J, Masoumi F, Nekoofar MH and Dummer PM: In vitro cytotoxicity of four calcium silicate-based endodontic cements on human monocytes, a colorimetric MTT assay. Restor Dent Endod 39: 149-154, 2014.

290. Chiang YC, Chang HH, Wong CC, Wang YP, Wang YL, Huang $W H$ and Lin CP: Nanocrystalline calcium sulfate/hydroxyapatite biphasic compound as a TGF- $\beta 1 /$ VEGF reservoir for vital pulp therapy. Dent Mater 32: 1197-1208, 2016.

This work is licensed under a Creative Commons Attribution-NonCommercial-NoDerivatives 4.0 International (CC BY-NC-ND 4.0) License. 